\title{
Article \\ RAR $\beta$ Expression in Keratinocytes from Potentially Malignant Oral Lesions: The Functional Consequences of Re-Expression by De-Methylating Agents
}

\author{
Raghu Radhakrishnan ${ }^{1,2}{ }^{(D}$, Hannah L. Crane ${ }^{2}$, Marc Daigneault ${ }^{3}\left(\mathbb{D}\right.$, Kanaka Sai Ram Padam $^{4}(\mathbb{D}$ \\ and Keith D. Hunter $2,5, *$ (D) \\ 1 Oral Pathology, Manipal College of Dental Sciences, Manipal Academy of Higher Education, \\ Manipal 576104, India; raghu.ar@manipal.edu \\ 2 Academic Unit of Oral and Maxillofacial Medicine and Pathology, School of Clinical Dentistry, \\ University of Sheffield, Sheffield S10 2TN, UK; h.crane@sheffield.ac.uk \\ 3 Medicines Discovery Catapult, Mereside, Alderley Park, Alderley Edge, Cheshire SK10 4TG, UK; \\ marc.daigneault@md.catapult.org.uk \\ 4 Cell and Molecular Biology, Manipal School of Life Sciences, Manipal Academy of Higher Education, \\ Manipal 576104, India; kanaka.sairam@learner.manipal.edu \\ 5 Departmentt of Oral Pathology and Oral Biology, Faculty of Dentistry, University of Pretoria, \\ Pretoria 0002, South Africa \\ check for \\ * Correspondence: k.hunter@sheffield.ac.uk
} updates

Citation: Radhakrishnan, R.; Crane, H.L.; Daigneault, M.; Padam, K.S.R.; Hunter, K.D. RAR $\beta$ Expression in Keratinocytes from Potentially Malignant Oral Lesions: The Functional Consequences of Re-Expression by De-Methylating Agents. Cancers 2021, 13, 4064. https: / / doi.org/10.3390/ cancers 13164064

Academic Editors: Pierre Saintigny, Senada Koljenović, Paolo Bossi and Jebrane Bouaoud

Received: 2 July 2021

Accepted: 11 August 2021

Published: 12 August 2021

Publisher's Note: MDPI stays neutral with regard to jurisdictional claims in published maps and institutional affiliations.

Copyright: (c) 2021 by the authors. Licensee MDPI, Basel, Switzerland. This article is an open access article distributed under the terms and conditions of the Creative Commons Attribution (CC BY) license (https:// creativecommons.org/licenses/by/ $4.0 /)$.
Simple Summary: Patients may develop white or red patches of the lining of the mouth with an increased risk of developing oral cancer. Treatment with Vitamin A derivatives (retinoids) results in some improvement in these lesions, but this is not maintained, and there are side effects. We know that the cells of the mouth lose cellular receptors for retinoids as these lesions develop, initially by a reversible alteration to the DNA (DNA methylation). Drugs, such as 5-AZA-CdR, which reduce DNA methylation, may restore sensitivity to the effects of retinoids. Treatment of a panel of cells from mouth precancer white patches with retinoids, 5-AZA-CdR and a combination results in varied responses: some cells re-sensitise to retinoids, whereas in others, the main effects on cell division rate and cell lifespan seem related to the effects of 5-AZA-CdR alone. These findings help us to understand the varied responses to retinoids in the clinical setting.

Abstract: Loss of RAR $\beta 2$ expression by promoter methylation is an early event in oral carcinogenesis. Understanding the mechanisms and consequences of RAR $\beta$ loss may aid in understanding the disappointing results of retinoid chemoprevention trials. This study aimed to describe the effects of all-trans retinoic acid (ATRA) and the de-methylating agent 5-Aza-2' deoxycytidine (5-AZA-CdR) on a panel of immortal potentially malignant oral lesion (PMOL) cell cultures. RAR $\beta$ expression was assessed in PMOL tissues by immunohistochemistry. Cells were treated with ATRA \pm 5-AZA-CdR, and the effects on the cell cycle and senescence were assessed. In PMOL tissues, RAR $\beta$ expression was variable, but lower in biopsies which gave rise to immortal cell cultures. Treatment of iPMOL cells with ATRA resulted in little change in RAR $\beta$ expression, but the addition of 5-AZA-CdR resulted in significant increases. The effects on the cell cycle and senescence were variable and may be related to 5-AZA-CdR, as this has wider effects on the cell cycle. Overall, the response of iPMOL cells to ATRA and 5-AZA-CdR treatment was variable and is dependent on several factors, including RAR $\beta$-promoter methylation. These findings may help to explain the lack of consistent effect of retinoids in PMOLs seen in chemoprevention trials.

Keywords: RAR $\beta$; oral cancer; oral potentially malignant lesions; PMOL; retinoids; chemoprevention 


\section{Introduction}

Potentially malignant oral lesions (PMOLs) present variably in the mouth, including white or red lesions (leukoplakia and erythroplakia). The risk of the development of oral squamous cell carcinoma (OSCC) in such lesions has been related to several factors, including patient age, the size, clinical appearance and site of the lesion, and degree of epithelial dysplasia [1,2]. There is, however, a lack of validated biomarkers for the prediction of malignant transformation [3]. Given the well-established concept of field cancerisation of the oral mucosa, it has been demonstrated that the underlying molecular lesion within the oral mucosa may be significantly more extensive than either the clinical or histological abnormality [4]. The extent of this genetic abnormality means that it may not be possible, or even desirable, to eradicate this by surgical means, even if the clinically evident lesion can be removed. Thus, there has been much interest in (chemo)prevention of progression to OSCC over many years.

Much of the interest in chemopreventative agents has focussed on Vitamin A and related compounds, often referred to collectively as retinoids. Initial studies used topical Vitamin A, but subsequent clinical investigations used a number of naturally occurring or synthetic analogues, including 13-cis-retinoic acid [5-7]. Several moderately sized clinical trials have been completed using these agents. Whilst initially promising, with reductions in the size of clinical lesions, the overall long-term outcomes in terms of cancer prevention were variable [6,8-10]. Additionally, some authors reported significant side effects and relapse of lesions after cessation of treatment [11]. In summarising this literature, the Cochrane review of interventions in oral leukoplakia concluded that there is currently insufficient high-quality evidence for any intervention which will reduce the malignant transformation rate in OPMLs [12]. This has resulted in less interest in the literature on the effects of retinoids and other vitamin A analogues for OSCC prevention in recent years.

The effects of retinoids on oral mucosa are complex. In general, treatment of oral epithelial cells with retinoids results in inhibition of cell proliferation and terminal differentiation [13]. The expression of certain retinoic acid receptors in normal oral keratinocytes depends on retinoid treatment. In some mortal cell cultures derived from PMOLs, constitutive expression of the retinoid receptor Retinoic Acid Receptor Beta (NR1B2, HGNC: 9865, hereafter referred to as RAR $\beta$ ) has been described [14]. However, in the progression of PMOLs to OSCC, loss of certain retinoid receptors has been described in both cell/tissue types, most notably the RAR $\beta$ isoform RAR $\beta 2[14,15]$. There are four isoforms of RAR $\beta$ which have been generated by alternative splicing (www.uniprot.org/uniprot/P1082, accessed on 5 August 2021). Loss of RAR $\beta 2$ has been associated with a number of other well-established alterations in oral epithelial cells on progression to OSCC via PMOLs, namely, loss of $\mathrm{p} 16^{\mathrm{INK} 4 \mathrm{a}}$ expression, p53 mutations and activation of telomerase [16]. This combination of alterations has been associated with the bypass of replicative senescence, allowing cells to become immortal. The basis of loss of RAR $\beta 2$ expression, which may occur at the PMOL stage, is hypermethylation of the RAR $\beta 2$ promoter [17]. The role of other associated molecules which are important in the modulation of retinoid receptor signalling, such as the cellular retinoid-binding proteins (cRPBs) [18], in this context is not known.

Various approaches have been reported to address these issues associated with retinoid therapy of PMOLs, including the use of newer synthetic retinoid analogues (for example, fenretinide: [9] and studies focussed on the identification of biomarkers, which may predict retinoid sensitivity [9,19-22]. A further possible approach has been used in other cancers: the addition of de-methylating agents to retinoids treatment. These agents, including 5-aza-2'-deoxycytidine (5-AZA-CdR), have been used clinically in the treatment of myelodysplastic syndromes and AML, where retinoid therapy is also employed. The effects of such combinations have been reported in vitro and in vivo clinical studies, with promising effects $[23,24]$. The approach has also been assessed in solid tumours, such as breast carcinoma and neuroblastoma $[25,26]$. Proof of principle has already been estab- 
lished in PMOL and OSCC cells [16,17], but an in-depth assessment of the functional effects in PMOLs has not been reported.

This raises the question of whether such an approach would be feasible in oral epithelial cells derived from PMOLs, laying the basis for possible clinical studies of such an approach in the chemoprevention of OSCC. In the present study, we aim to confirm the de novo methylation of RAR $\beta$ in oral epithelial dysplasia and understand its role in cellular immortalisation and abrogation of cellular senescence. We test the hypothesis that administration of 5-AZA-CdR alone and/or in combination with All trans-retinoic acid (ATRA) leads to re-expression of RAR $\beta$, reversal of immortalisation, and reinduction of the senescence programme in a panel of immortalised primary cultures.

\section{Materials and Methods}

\subsection{Cell Lines and Culture Conditions}

The experimental work described used a unique cohort of cell cultures derived from a variety of potentially malignant oral lesions (PMOL), all part of the Beatson Institute for Cancer Research cell culture collection. These have varied proliferative lifespans, with some undergoing replicative senescence (D6 and D30), whilst others are immortal (D19, D20, D34 and D38; Table 1). The p16-/TERT+ immortalised NOK culture FNB6 ${ }^{\text {TERT }}$ was used as a control. The molecular features that define these cultures have been previously described $[16,27]$. The cultures were maintained on an irradiated Swiss $3 \mathrm{~T} 3$ feeder layer in Green's medium at $37{ }^{\circ} \mathrm{C}$ with $95 \%$ humidity and $5 \% \mathrm{CO}_{2}$. The medium consisted of a 1:3 $(v / v)$ mixture of Dulbecco's modified Eagle's medium (DMEM) supplemented with $4500 \mathrm{mg} / \mathrm{L}$ glucose GlutaMAX ${ }^{\mathrm{TM}}$ I and sodium pyruvate (Gibco, Paisley, UK) and Ham's F12 medium supplemented with L-glutamine and sodium bicarbonate (Biosera, East Sussex, UK) with heat-inactivated fetal calf serum (Biosera, East Sussex, UK). This was supplemented with adenine $(0.025 \mu \mathrm{g} / \mathrm{mL})$ insulin $(5 \mu \mathrm{g} / \mathrm{mL}), 3,3$, 5-Triiodothyronine/Apo-Transferrin ( $1.36 \mathrm{ng} / \mathrm{mL} \mathrm{T3}$ and $5 \mu \mathrm{g} / \mathrm{mL}$ apo-transferrin), hydrocortisone $(4 \mu \mathrm{g} / \mathrm{mL})$, epidermal growth factor $(5 \mathrm{ng} / \mathrm{mL})$, amphotericin $B(0.625 \mu \mathrm{g} / \mathrm{mL})$, cholera toxin $(8.47 \mathrm{ng} / \mathrm{mL})$, penicillin $(100 \mathrm{IU} / \mathrm{mL})$, and streptomycin $(100 \mu \mathrm{g} / \mathrm{mL})$. The irradiated 3T3 feeder layer was removed by treatment with $0.05 \%$ trypsin $/ 0.02 \%$ EDTA $(w / v)$ (Sigma Aldrich, Dorset, UK) before keratinocyte trypsinisation.

Table 1. Details of the PMOL cell lines used in the study with original diagnosis and expression of RAR $\beta$ in the corresponding parent tissues.

\begin{tabular}{|c|c|c|c|c|c|}
\hline Cell Type & Site & Clinical Type & Dysplasia Grade & Phenotype & RAR $\beta$ Expression (\%) \\
\hline D6 & Posterior tongue & Leukoplakia & Moderate & Mortal (25PD) & 59.2 \\
\hline D30 & Floor of the mouth & Leukoplakia & Mild & Mortal (30PD) & 60.0 \\
\hline D19 & Lateral tongue & Erythroplakia & CIS & Immortal & 4.4 \\
\hline D20 & Lateral tongue & Leukoplakia & Moderate & Immortal & 20.1 \\
\hline D34 & $\begin{array}{l}\text { Posterolateral } \\
\text { tongue }\end{array}$ & Leukoplakia & Moderate & Immortal & 25.1 \\
\hline D38 & Lateral tongue & Leukoplakia & Mild & Immortal & 13.7 \\
\hline
\end{tabular}

\subsection{ATRA and 5-Aza-CdR Treatment of Cells}

All-trans-retinoic acid (Sigma-Aldrich, Dorset, UK), dissolved in dimethyl sulfoxide (DMSO) at a concentration of $10^{-2} \mathrm{M}$, and stored in dark at $-70^{\circ} \mathrm{C}$, was diluted in growth medium to a final concentration of $10^{-6} \mathrm{M}$ immediately before each experiment. Control cultures received the same amount of DMSO as treated cultures. 5-aza-2'-deoxycytidine (5-Aza-CdR) (Sigma, St. Louis, MO, USA) was dissolved in DMSO at a concentration of $2 \times 10^{-3} \mathrm{M}$, stored in small aliquots the dark at $-70^{\circ} \mathrm{C}$. Cell lines were treated with $0.5 \mu \mathrm{M}$ of 5-Aza-CdR with media refreshed every $24 \mathrm{~h}$ for 5 consecutive days before genomic DNA and total RNA were extracted and tested for methylation status as well as restoration of RAR $\beta$ expression. RAR $\beta 2$ induction was analysed in the cells treated using 1,5 , or $10 \mu \mathrm{M}$ 
of ATRA for 3 days. Untreated cells were used as an experimental control, and cells treated with a working concentration of DMSO were used as solvent control.

\section{3. cDNA Synthesis and RT-qPCR}

Total RNA from the cultured cell lines was isolated using RNeasy Mini Kit (Qiagen, Manchester, UK) and treated with DNase I (Qiagen, Valencia, CA, USA). The quantity and quality of DNA and RNA were analysed by 1000 NanoDrop Spectrophotometer V3.7 (Thermo Scientific, Hemel Hempstead, UK). An input amount of $2 \mu \mathrm{g}$ was used for Reverse transcription PCR, and cDNA synthesis was performed using a High Capacity cDNA Reverse Transcription kit (Applied Biosystems, Foster, CA, USA) following manufacturer's instructions in the DNA Engine Dyad thermal cycler (Bio-Rad, Hercules, CA, USA).

Quantitative real-time PCR (qPCR) was performed using ABI Prism 7900 Fast Sequence Detection Instrument (Applied Biosystems, Foster, CA, USA) for the relative gene expression of RARß2 (Hs00977141_mH), CDKN2A, (Hs99999189_m1), CDKN1A (Hs00355782_m1), IVL (Hs00846307_s1), ITGB1 (Hs05351551_g1), and CRBP1 (Hs01011512_g1), with $\beta$-2-microglobulin (B2M) (Assay ID: Hs99999907_m1) as a housekeeping gene using Taqman Assays procured from Thermo Fisher Scientific. All experiments were performed in triplicate, analysis was carried out using $2^{-\Delta C t}$ method [28] to calculate the mRNA expression relative to the $\mathrm{B} 2 \mathrm{M}$, and data was represented as mean with standard error.

\subsection{Western Blotting}

Following trypsinisation, cells (D6, D30, D34, D38, D19, D20, FNB6) were washed in $1 \times$ PBS ( $\mathrm{pH}$ 7.0) and lysed in RIPA buffer (Sigma Aldrich, Poole, UK) containing protease and phosphatase inhibitors (Roche, West Sussex, UK). Protein preparation was carried out by centrifugation of cells at $12,000 \mathrm{rpm}, 4^{\circ} \mathrm{C}$ for $20 \mathrm{~min}$, following which the supernatant was aspirated. The total protein concentration was determined using Pierce BCA Protein Assay Kit as per the manufacturer's protocol (Thermo Scientific, Hemel Hempstead, UK). A total of $20 \mu \mathrm{g}$ of total protein was loaded onto $4-12 \%$ polyacrylamide precast gels (NuPAGE ${ }^{\text {TM }} 4$ to $12 \%$, Bis-Tris, $1.0 \mathrm{~mm}$, Mini Protein Gel, Novex, Thermo Scientific, Hemel Hempstead, UK). After transferring the gel onto nitrocellulose membrane using an iBlot Dry Blotting System (Life Technologies, Carlsbad, CA, USA) for 7 min, the membranes were washed with Tris buffer and blocked with 5\% dried milk in Tris-buffered saline (TBS) containing $0.05 \%$ Tween-20, for $1 \mathrm{~h}$ and incubated overnight at $4{ }^{\circ} \mathrm{C}$ with the following primary monoclonal antibodies: (Anti-RAR $\beta$ antibody (EPR2017; (ab124701)) at 1/1000 dilution; Anti-p21 antibody (EPR18021; (ab188224)) at 1/1000 dilution; AntiCDKN2A/p16INK4a antibody (DCS50.1; (ab16123)) at 1/5000 dilution and incubated for $1 \mathrm{~h}$ with primary anti- $\beta$-actin antibody (1:5000), Sigma Aldrich, Poole, UK). Membranes were then incubated in horseradish peroxidase (HRPO) conjugated with anti-rabbit IgG (1:3000, ab6721, Abcam (Cambridge, UK)) for $1 \mathrm{~h}$ and developed with SuperSignal West Pico chemiluminescent substrate (Thermo Scientific, Hemel Hempstead, UK). HeLA and irradiated $3 \mathrm{~T} 3$ cells' lysate were used as experimental controls.

\subsection{Growth Inhibition Assay and Flow Cytometry}

Cells were seeded at a density of $1 \times 10^{5}$ cells/well in a 6-well plate as required. Post $24 \mathrm{~h}$, the cells were treated with different concentrations of ATRA, $0.5 \mu \mathrm{M} 5$-Aza-CdR and a combination of $0.5 \mu \mathrm{M} 5$-Aza-CdR and $1 \mu \mathrm{M}$ ATRA for 3 days in Green's medium containing 10\% FCS. The cells after the treatment were labelled with EdU (5-ethynyl-2'-deoxyuridine) at a concentration of $10 \mu \mathrm{M}$ for $1-2 \mathrm{~h}\left(\right.$ Click-iT $^{\circledR}$ EdU Alexa Fluor ${ }^{\mathrm{TM}} 488$ Assay Kits for Flow Cytometry, Life technologies; excitation $488 \mathrm{~nm} /$ emission $530 \mathrm{~nm}$ ). EdU is a nucleoside analogue to thymidine and is incorporated into DNA during active DNA synthesis. Following EdU labelling, the cells were washed once with $3 \mathrm{~mL}$ of $1 \%$ BSA in PBS, pelleted, and the supernatant removed. The cell pellet was dislodged, and $100 \mu \mathrm{L}$ of Click-iT ${ }^{\circledR}$ fixative was added and mixed well. Cells were incubated for $15 \mathrm{~min}$ in the dark, then washed once with $3 \mathrm{~mL}$ of 1\% BSA in PBS, pelleted, and the supernatant removed. Cells were 
resuspended in $100 \mu \mathrm{L}$ of $1 \times \mathrm{Click}^{-i \mathrm{~T}^{\circledR}}$ saponin-based permeabilisation and wash reagent and mixed well and incubated. Appropriate amounts of Click-iT ${ }^{\circledR}$ Plus reaction cocktail was used within $15 \mathrm{~min}$ of preparation, and $0.5 \mathrm{~mL}$ of Click-iT ${ }^{\circledR}$ Plus reaction cocktail was added for each tube, mixed well, and incubated for $30 \mathrm{~min}$ and protected from light. Following this, the cells were washed once with $3 \mathrm{~mL}$ of $1 \times \mathrm{Click}^{-i \mathrm{~T}}{ }^{\circledR}$ saponin-based permeabilisation and wash reagent and resuspended in $500 \mu \mathrm{L}$ of $1 \times$ Click-iT $^{\circledR}$ saponin-based permeabilisation and wash reagent. A total of $50 \mu \mathrm{L}$ of RNase $(100 \mu \mathrm{g} / \mathrm{mL}$ solution) was added and incubated for $15 \mathrm{~min}$ at $37^{\circ} \mathrm{C}$. Finally, the nucleic acid dye, TO-PRO-3 (Thermo Fisher Scientific, excitation $643 \mathrm{~nm} /$ emission $661 \mathrm{~nm}$ ), was added at a concentration of $0.1 \mu \mathrm{M}$ and incubated for $15 \mathrm{~min}$ in the dark. Samples were analysed by flow cytometry using an LSRII flow cytometer (Becton Dickinson, Oxford, UK) and FACSDiva ${ }^{\mathrm{TM}}$ versio 7 acquisition software (Becton Dickinson, Oxford, UK). Cells were gated based on forward (FSC) and side (SSC) light scatter, and 10,000 events per sample were recorded. Data were analysed using FlowJo analysis software v7.6.5 (Tree star Inc, Ashland, OR, USA). Apoptotic cells in the sub-G0 region were excluded, and standard flow cytometry methods were used for determining the percentage of G1/S/G2-phase cells in the population, as previously described [29].

\subsection{Promoter Methylation Analysis}

Promoter methylation analysis was performed by MethylScreen technology [30], using EpiTect Methyl II PCR Assay kit, Qiagen. Briefly, genomic DNA was extracted and purified from the treated and untreated PMOL cell lines using QIAmp DNA mini kit and aliquoted in equal amounts of DNA (250 ng) into four tubes labelled mock (M0), methylation-sensitive (Ms), methylation-dependent (Md), and methylation-sensitive-dependent (Msd) restriction enzymes. All four cocktail reaction tubes were incubated at $37{ }^{\circ} \mathrm{C}$ for $6 \mathrm{~h}$ and then at $65{ }^{\circ} \mathrm{C}$ for 20 min using DNA Engine Dyad thermal cycler (Bio-Rad, Hercules, CA, USA). Quantitative PCR for determination of methylation status was performed in ABI Prism 7900 Fast Sequence Detection Instrument (Applied Biosystems, Foster, CA, USA) using $5 \mu \mathrm{L}$ of remaining input genomic DNA post the restriction digestion with qPCR master mix (RT2 qPCR SYBR Green/ROX Master Mix, Qiagen, Manchester, UK: Cat number 330520), and were dispensed into a PCR array plate containing pre-aliquoted primer mixes (EpiTect Methyl II qPCR Primer Assay) according to manufacturer instructions. Thermal cycling conditions used were: $95^{\circ} \mathrm{C}$ for $10 \mathrm{~min}(1 \mathrm{cycle})$, then $99{ }^{\circ} \mathrm{C}$ for $30 \mathrm{~s}$ and $72{ }^{\circ} \mathrm{C}$ for $1 \mathrm{~min}$ (3 cycles), and finally, $97^{\circ} \mathrm{C}$ for $15 \mathrm{~s}$ and $72{ }^{\circ} \mathrm{C}$ for $1 \mathrm{~min}$ (40 cycles). The raw $\mathrm{Ct}$ values obtained post the run were pasted into EpiTect Methyl II PCR Array Microsoft Excel-based data analysis template (supplied), which automatically calculates the relative amount of methylated and unmethylated DNA fractions.

\subsection{Methylation-Specific PCR (MSP) and Bisulfite PCR for Restriction Analysis}

The promoter methylation status of RAR $\beta$ was determined by MSP. Briefly, $2 \mu \mathrm{g}$ of genomic DNA was treated with sodium bisulfite for $16 \mathrm{~h}$. Following this, DNA was desulfonated and purified using the Wizard DNA Clean-up system (Promega, Madison, WI, USA). An input quantity of $2 \mu \mathrm{L}$ of converted DNA was used as a template for performing MSP with two sets of primers to differentiate between methylated and unmethylated regions as described [31]. The primer sequences specific for methylated sodium bisulfite DNA (FP: 5'-TCGAGAACGCGAGCGATTCG-3' (sense) and RP: 5'-GACCAATCCAACCGAAACGA$3^{\prime}$ (anti-sense); $146 \mathrm{bp}, \mathrm{T}_{\mathrm{H}}-58^{\circ} \mathrm{C}$ ) and those for unmethylated sodium bisulfite DNA (FP: $5^{\prime}$-TTGAGAATGTGAGTGATTTGA-3' (sense) and RP: 5'-AACCAATCCAACCAAAACAA$\left.3^{\prime} ; 146 \mathrm{bp}, \mathrm{T}_{\mathrm{H}}-50{ }^{\circ} \mathrm{C}\right)$ were used [32].

Furthermore, methylation of the RAR $\beta$-promoter region was determined using combined bisulfite PCR followed by restriction analysis as described earlier (COBRA) [33]. The primer sequences used for amplifying the modified DNA were forward: 5'-AAGTAGTAGGAAGTGAGTTGTTTAGA-3' and reverse: 5'-CCAAATTCTCCTTCCAAATAA$3^{\prime}$ yields an amplicon of $207 \mathrm{bp}$ product as published [17]. The amplified products were 
then digested with Tail for RAR $\beta 2$ (MBI Fermentas, Hanover, Germany) and subjected to electrophoresis on 3\% agarose gel and visualised using ethidium bromide. Human methylated lymphocyte DNA generated in vitro by CpG methyltransferase (SssI; New England Biolabs, Inc., Beverly, MA, USA) was used as a positive control and the non-template (negative) control was included as in every PCR run.

\subsection{DNA Cloning and Sequencing}

Primers employed to generate the target region of interest for cloning were the same used for COBRA to clone DNA fragments into a Pcr2.1 TOPO vector (Invitrogen Corporation, Carlsbad, CA, USA) according to manufacturer's instructions. The generated vector construct was then transformed into chemically competent $E$. coli, and positive colonies were selected based on blue-white screening for propagation. Plasmid DNA was extracted and purified using Qiagen Plasmid Mini Kit (Qiagen, Valencia, CA, USA) and sequenced using ABI PRISM 377 DNA sequencer (Applied Biosystems, Foster, CA, USA) at the DNA-sequencing core facility at the University of Sheffield, UK.

\subsection{Immunofluorescence}

Cells were plated in eight-well glass chamber slides (Thermo Scientific ${ }^{\mathrm{TM}} \mathrm{Nunc}^{\mathrm{TM}} \mathrm{Lab}-$ Tek $^{\mathrm{TM}}$ Chamber Slide System) prior to processing. The $1 \times 10^{4}$ cells (D19, D20, D34, D38 and FNB6) were seeded onto coverslips and cultured until they reached $95 \%$ confluence. Cells were fixed in $4 \%$ paraformaldehyde for $15 \mathrm{~min}$ and permeabilised using Triton-X-100 (Sigma, Poole, UK) for 15 min. Blocking of non-specific binding was carried out using unlabelled serum from the same species as the second antibody for $1 \mathrm{~h}$ at room temperature. Samples were incubated with the primary antibody Anti-HIRA/HIR antibody (EPR7416) (ab129169) at 1:200 dilution at $4{ }^{\circ} \mathrm{C}$ overnight. Goat anti-rabbit IgG (Alexa Fluor ${ }^{\circledR} 488$, ab150077) was used as the secondary antibody at 1:1000 (2 $\mathrm{g} / \mathrm{mL})$ dilution for $1 \mathrm{~h}$ at room temperature (RT). Cells were counterstained with DAPI (Invitrogen) for $10 \mathrm{~min}$ at RT in the dark. $1 \times$ PBS with $0.05 \%$ Tween-20 was used throughout the protocol for adequate washing. Coverslips were mounted on microscopic slides with antifade solution (VectaShield, Vector Laboratories, Burlingame, CA, USA). Cells incubated with IgG and secondary antibodies served as a background control. Stained cells were examined using a Leica DMRB fluorescence microscope and $\times 40 / 0.7$ objective lens (Leica Microsystems, Wetzlar, Germany); for these experiments, image processing was performed by LAS AF software (Leica Microsystems). Three or more foci per nucleus were considered to be positive for HIRA.

\subsection{Senescence $\beta$-Galactosidase Staining}

Senescent keratinocytes were identified using Senescence $\beta$-Galactosidase Staining Kit (Cell Signalling Technology, Inc., Beverly, MA, USA). $\beta$-Galactosidase Staining Solution at final pH of 6.0 stain positively for senescent cell, as described by [34]. Briefly, cells were grown on a $35 \mathrm{~mm}$ Petri dish, washed once with PBS, fixed with PBS containing $2 \%$ formaldehyde and $0.2 \%$ glutaraldehyde, then washed in PBS supplemented with $1 \mathrm{mM}$ $\mathrm{MgCl}_{2}$. Cells were stained in senescence-associated $\beta$-galactosidase staining solution (150 mM NaCl, $2 \mathrm{mM} \mathrm{MgCl}$, $5 \mathrm{mM}$ potassium ferricyanide, $40 \mathrm{mM}$ citric acid, and $12 \mathrm{mM}$ sodium biphosphate, at $\mathrm{pH}$ 6.0. containing $1 \mathrm{mg} / \mathrm{mL}$ of 5-Bromo-4-chloro-3-indolyl $\beta$-Dgalactoside overnight at $37^{\circ} \mathrm{C}$ in a dry incubator without $\mathrm{CO}_{2}$. The plates were sealed with parafilm to prevent evaporation. For long-term storage of the plates, staining solution was removed, and the cells were overlayed with $70 \%$ glycerol and stored at $4{ }^{\circ} \mathrm{C}$. To ensure a representative count, each culture was divided into quarters, and at least two fields were photographed with an Olympus IMT-2 phase-contrast microscope. A minimum of 500 cells was counted on each occasion. The percentage of senescent cells present was defined as the percentage of senescence-associated $\beta$-galactosidase positive cells out of the total number of cells present. Average percentages and SD were calculated from three independent experiments. 


\subsection{Tissue-Engineered Oral Mucosa}

De-epidermised acellular dermis was incubated in fresh DMEM for $48 \mathrm{~h}$ at $37^{\circ} \mathrm{C}$ to confirm sterility. Processed DED was cut into $2 \mathrm{~cm} \times 2 \mathrm{~cm}$ squares and placed into 6-well plates submerged in Green's media. Chamfered surgical stainless-steel rings with an internal diameter of $8 \mathrm{~mm}$ were pushed onto the DED to provide a liquid-tight seal. For the tissue-engineered dysplastic oral mucosa models (TEDOM), $2.5 \times 10^{5}$ D6, D30, D34, D38, D19 and D20 cells and $5 \times 10^{5}$ normal oral fibroblasts (NOFs) was used. Medium within the ring was replaced after 24 and $48 \mathrm{~h}$. After $72 \mathrm{~h}$, the ring was removed, and the composites were placed onto stainless steel grids with medium added to the underside of the composite model to allow culture at the air-to-liquid interface. For all models, the medium was changed 2-3 times/week, and the composites were fixed at day 14 for TEDOM in $10 \%$ buffered formalin for $48 \mathrm{~h}$ [35].

\subsection{Patient Tissue Samples and Immunohistochemistry}

Two cohorts of patient samples were analysed by immunohistochemistry: one whose samples directly matched the cell cultures used in the main part of the project $(n=6)$ and a separate, unrelated cohort of oral premalignant lesions $(n=10)$. Oral precancerous tissues from surgically excised oral dysplasia lesions representing different grades of dysplasia and adjacent normal mucosal tissue from the archive of the Department of Oral and Maxillofacial Pathology, University of Sheffield. RAR $\beta$ expression was assessed by immunohistochemistry in a cohort of dysplastic lesions of various grades with a particular emphasis on tissue heterogeneity. All the original histological diagnoses were reviewed by two independent examiners (RR and $\mathrm{KDH}$ ). Then, $4 \mu \mathrm{m}$ sections were cut from FFPE blocks and mounted on APES coated slides. Deparaffinization and hydration of the tissue sections were carried out through two changes of xylene and graded alcohols. Heat-induced antigenic epitope retrieval was carried out in Sodium citrate buffer $(10 \mathrm{mM}$ Sodium Citrate, $0.05 \%$ Tween-20, pH-6.0). After washing sections twice in TBS $+0.025 \%$ Triton-X-100 with gentle agitation, sections were blocked in 10\% normal serum with $1 \%$ BSA in TBS for $2 \mathrm{~h}$ at room temperature. After draining slides, an anti-RAR $\beta$ antibody (EPR2017) (ab124701) was added at 1:100 dilution in TBS with $1 \%$ BSA and incubated overnight at $4{ }^{\circ} \mathrm{C}$. The following day, sections were rinsed twice in TBS with $0.025 \%$ Triton-X-100 with gentle agitation. Sections were then incubated in a biotinylated secondary antibody (Vectastain Elite ABC Kit) for $30 \mathrm{~min}$. Following a $2 \times 5 \mathrm{~min}$ wash in TBS, sections were incubated with VECTASTAIN Elite $A B C$ reagent for $30 \mathrm{~min}$, washed, and visualisation was developed with 3,3'-Diaminobenzidine (DAB). Eventually, sections were counterstained, dehydrated, cleared, and mounted.

Each spot image was submitted to colour deconvolution to separate the blue colour from haematoxylin and the brown colour from DAB using the plugin in ImageJ software (National Institute of Health, Bethesda, MD, USA). The positive labelling (brown colour) was selected using the threshold tool of ImageJ (from 0 to 127 brown tones). First, the image was processed by colour deconvolution using the two vectors, hematoxylin and DAB. Assessment of intensity was not carried out as the immunostains are not stoichiometric. Then, the processed image was adjusted for optimal threshold. The upper and the lower limit for both the DAB alone and hematoxylin was adjusted and the particles in both were separately analysed. The final score was calculated as ((positive labelling area/tumour area) $\times 100)$ ). A qualitative interpretation of immunohistochemical signal was performed, blinded to diagnosis and clinical data.

\subsection{Statistical Analysis}

The data analysed was represented as mean with standard error derived from at least three independent experiments. Comparisons among the groups were performed using one-way ANOVA followed by post hoc Tukey's test or Dunnett's test. Comparison between the two groups was performed using paired or unpaired $t$-tests. All the statistical analysis mentioned was performed using GraphPad prism statistical software 
v8.0 (GraphPad Software Inc., San Diego, CA, USA). A $p$-value of $<0.05$ was considered statistically significant.

\section{Results}

3.1. RARß2 Expression Is Lost in iPMOL Cultures and Reduced in Their Matched Tissues, but Expression Varies in All PMOL Tissues

RAR $\beta 2$ is expressed by mortal PMOL cells (D6 and D30), whereas expression has been lost in immortal OPML (iPMOL) cell cultures (D19, D20, D34 and D38) and the immortalised NOK culture FNB6 (Figure 1A), as assessed by qPCR. Total RAR $\beta$ protein expression was reduced in iPMOL cells (Figure 1B). In keeping with earlier reported patterns of expression in these cells, there is lower p16 and p21 expression in the immortal cells $[14,16,27]$. Markers of differentiation (IVL and ITB1) and expression of cRBP1 are also reduced in iPMOL cells (Figure 1A,B).

The extent of RAR $\beta$ expression in the biopsy samples matched to the cell cultures shows that RAR $\beta$ expression was lower in the tissues that gave rise to immortal cell cultures (Figure 1C; Table 1). This indicates that the loss of RAR $\beta$ expression is not merely an in vitro phenomenon. Nevertheless, all tissues did express RAR $\beta$ to some extent, indicative of a mixed cell population in these PMOL tissues, as we have previously suggested [36]. Expression of RAR $\beta$ in an extended clinical cohort $(n=10)$ confirmed this heterogeneity in the expression of RAR $\beta 2$ (Figure 1D). The proportion of cells expressing RAR $\beta 2$ was variable and was not directly related to the grade of epithelial dysplasia (Table 2). The expression of cRBP1 in this biopsy cohort was very variable. RAR $\beta$ staining in the $3 \mathrm{D}$ tissueengineered oral mucosa (TEM) models developed from iPMOLs showed a heterogeneous staining pattern, but which was higher overall than in the parent tissue biopsies (Figure 1E).

Table 2. Details of the extended OED patient cohort.

\begin{tabular}{cccccc}
\hline No & Sex & Age & Site & $\begin{array}{c}\text { Epithelial } \\
\text { Dysplasia }\end{array}$ & $\begin{array}{c}\text { Mean } \\
\text { RAR } \boldsymbol{\beta} \%\end{array}$ \\
\hline P1 & F & 75 & Mandibular Gingiva & Mild & 51.2 \\
P2 & M & 71 & Ventral Tongue & Moderate & 57.0 \\
P3 & M & 36 & Floor of mouth & Severe & 44.9 \\
P4 & M & 60 & Soft Palate & Mild & 53.2 \\
P5 & F & 57 & Floor of mouth & Moderate & 32.8 \\
P6 & M & 73 & Lateral Tongue & Mild & NED \\
P7 & M & 57 & Ventral Tongue & Mild & 60.9 \\
P8 & M & 62 & Lateral Tongue & Moderate & 46.1 \\
P9 & M & 42 & Lateral Tongue & Severe & 41.0 \\
P10 & M & 41 & Ventral Tongue & Moderate & 43.1 \\
\hline
\end{tabular}

NED: no expression detected. 


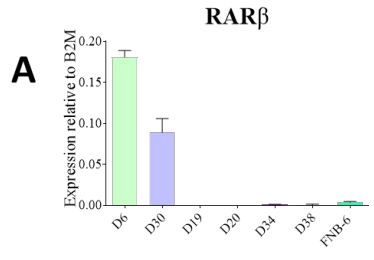

CDKN1A

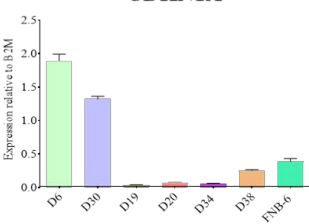

ITGB1

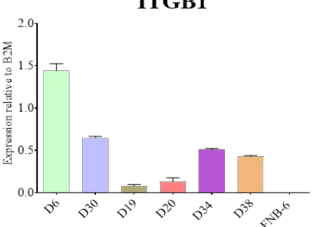

B

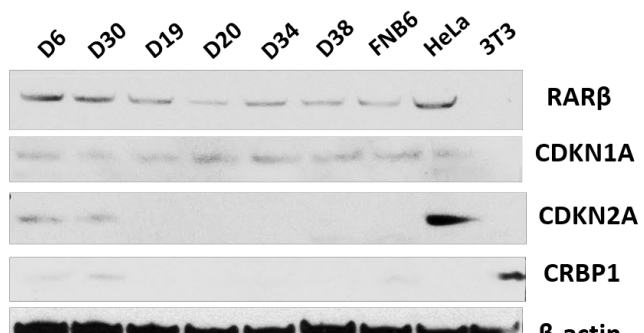

CRBP1

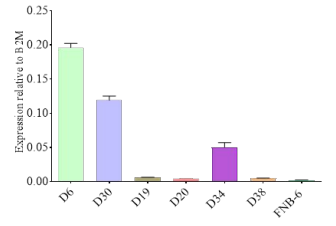

CDKN2A
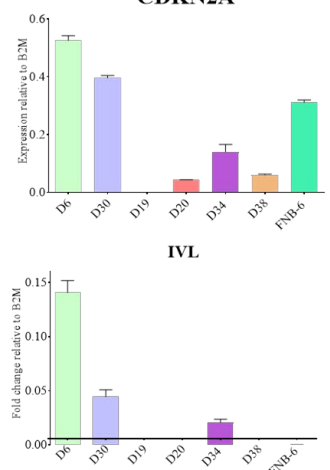

D

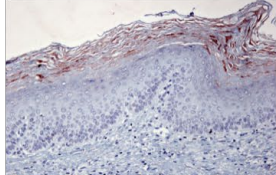

Mild Dysplasia

RAR $\beta$ - No staining

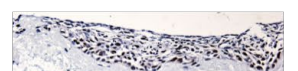

E

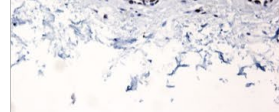

D19 - RARß (20.6\%)

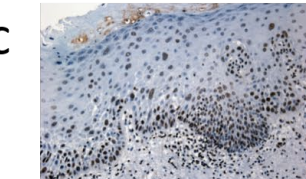

D6 - RARß (59.2\%)

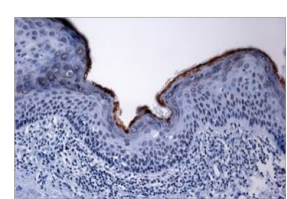

D19 - RARB (4.4\%)

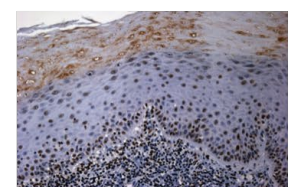

D30 - RARß (60.4\%)

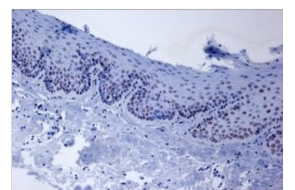

D20 - RARß (20.1\%)

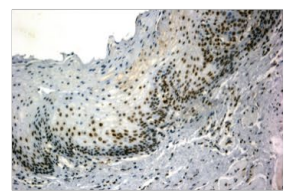

Moderate Dysplasia RARß $-53.9 \%$

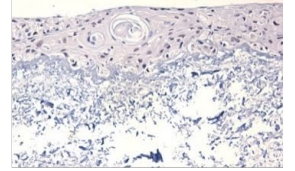

D20 - RARß (47.1\%)

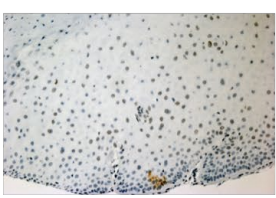

D34- RARß (25.1\%)

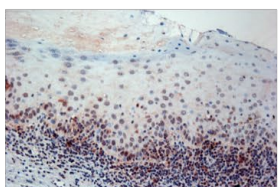

Moderate Dysplasia RARB - 46.1\%

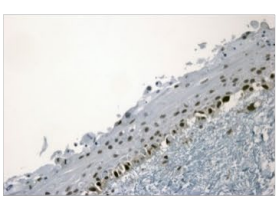

D34 - RARß (32.6\%)

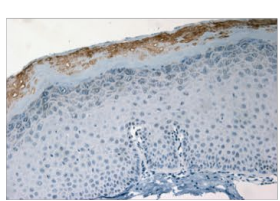

D19- RARß (13.7\%)

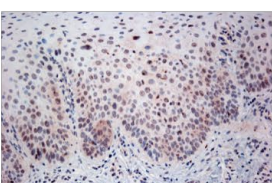

Severe Dysplasia

RAR $\beta-41.4 \%$

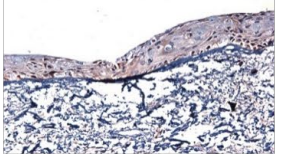

D38 - RARß (17.1\%)

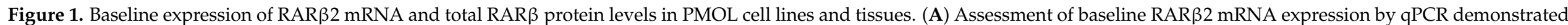

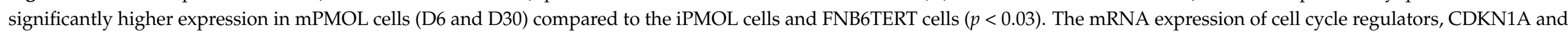

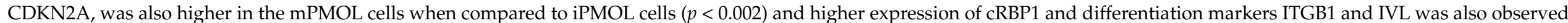

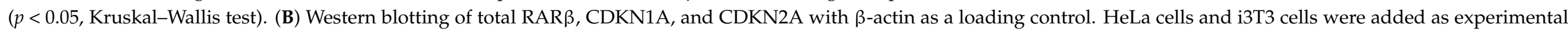

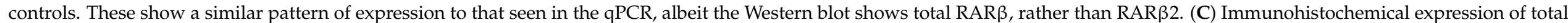

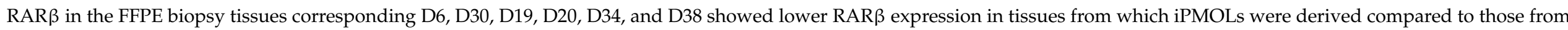

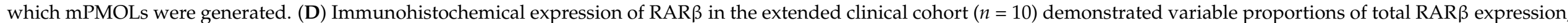

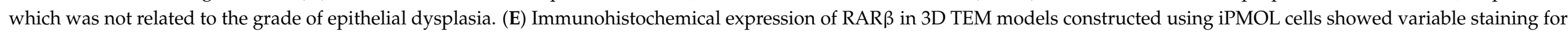
RAR $\beta$, but in every case, higher than in the matched biopsy material (Figure $2 \mathrm{C}$ ). 
A

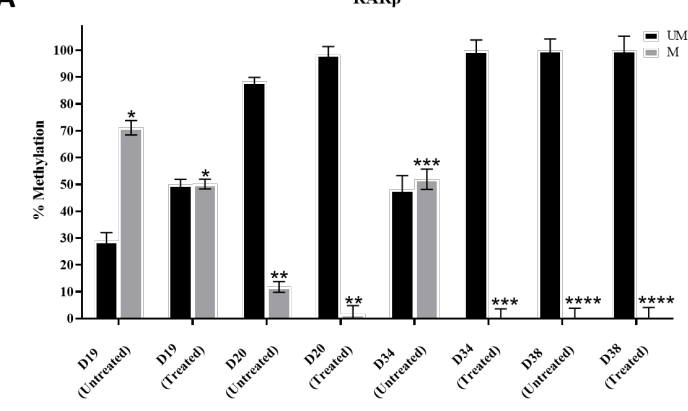

B
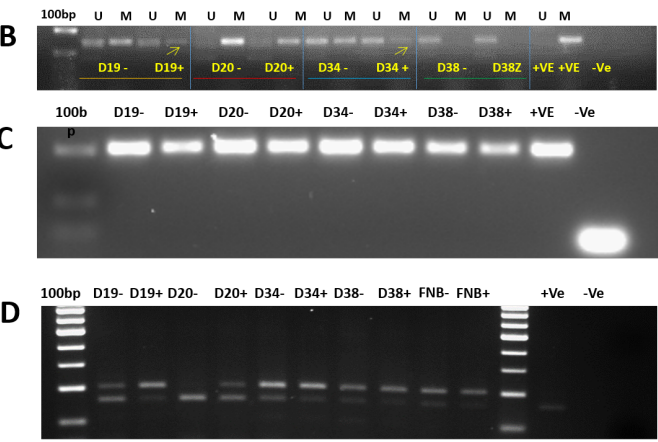

E D19 (-)

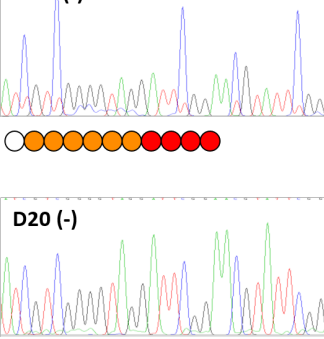

00000000000

D34 (-)

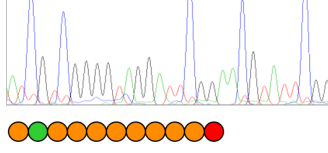

D38 (-)

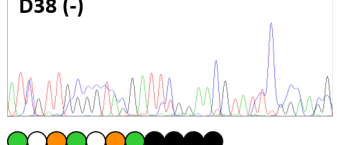

D19 $(+)$

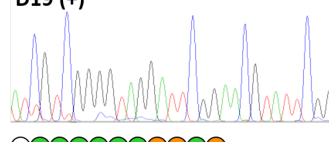

00000000000

D20 (+)

\section{$1+1$}

00000000000

D34(+)

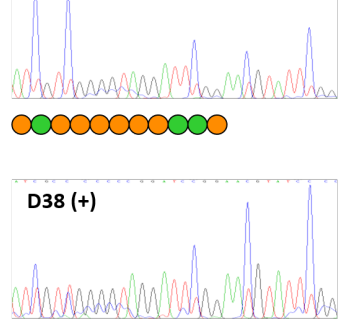

00000000000

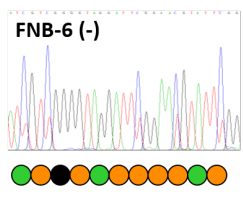

FNB-6 (+)

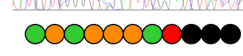

Positive Control

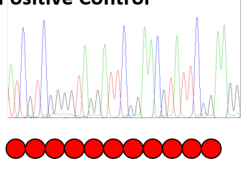

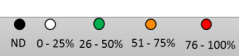

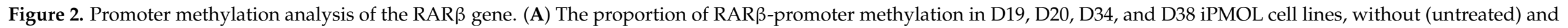

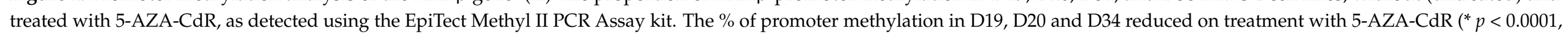

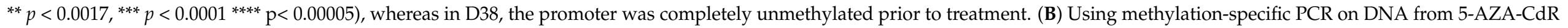

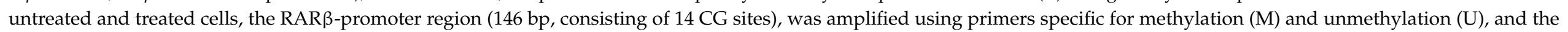

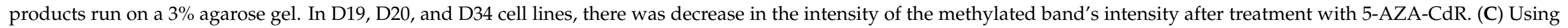

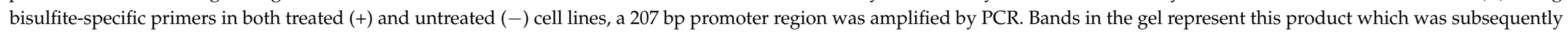

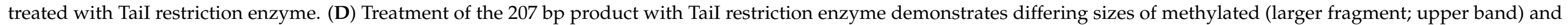

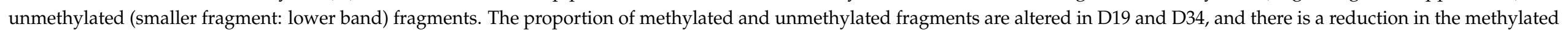

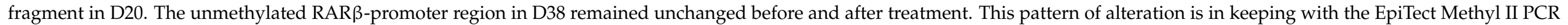

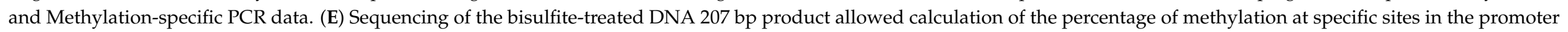

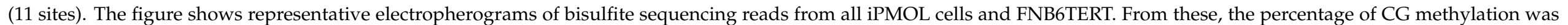

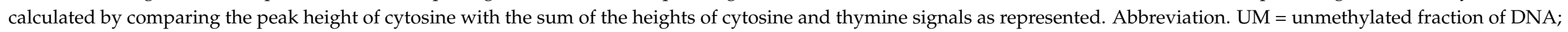
$\mathrm{M}=$ methylated fraction of DNA; $(+)$ treated; $(-)$ untreated. 


\subsection{The RARß-Promoter Was Hypermethylated in 3/4 Immortal Oral Dysplastic Cell Lines}

Analysis of DNA methylation of the RAR $\beta$-promoter region was performed using Epitect Methyl II qPCR assay specific for RAR $\beta$-promoter CpG island (GenBank: X56849.1). The RAR $\beta$ promoter was hypermethylated in D19 and D34 cells, with the methylated fraction of DNA noted to be $71.12 \%$ and $51.91 \%$, respectively. A significant reduction in methylation was noted after treatment with 5-AZA-CdR $(p<0.001)$. The methylation level in the D20 cells was $11.76 \%$, which was lower than seen in D19 and D34. However, significant de-methylation was noted upon treatment with 5-AZA-CdR $(p<0.0017)$. In D38, the RAR $\beta$ promoter was unmethylated and showed no change with treatment (Figure 2A).

To eliminate the potential false positives and to confirm the extent of methylation, methylation-specific PCR was carried out. Methylation-specific PCR of bisulfite-treated DNA from four IMDs showed a $146 \mathrm{bp}$ transcript using primers specific for methylated $(\mathrm{M})$ and unmethylated (U) DNA in the untreated $(-)$ and treated $(+)$ cells. A reduction in the band intensity in D19 and D34 and a modest reduction in D20 were noticed when treated with $2 \mu \mathrm{M}$ 5-AZA-CdR. The D38 cells remained unchanged in both the methylated $(\mathrm{M})$ and unmethylated (U) lanes before and after treatment (Figure 2B).

Further validation of DNA methylation and de-methylation by the action of 5-AZA$\mathrm{CdR}$ was confirmed by bisulfite sequencing. This was followed by COBRA, where a $207 \mathrm{bp}$ of bisulfite modified DNA of the promoter was amplified, and the PCR product was digested using the TaiI restriction enzyme, which specifically cuts at ACGT^ sites generating upper unmethylated and a lower methylated DNA fragment, whereas unmethylated DNA remained uncut (Figure 2C,D). Analysis of the 11 CG sites in all the iPMOL cells was determined by sequencing followed by comparing the peak height of cytosine with the sum of the height of cytosine and thymidine signals (Figure 2E).

3.3. Treatment with 5-Aza-CdR and ATRA Variably Alters Expression of $R A R \beta, p 16$, and $p 21$ in iPMOL Cells

The extent of expression of RAR $\beta$ in D19, D20, D34 and D38 was assessed after treatment of the cells with various concentrations of ATRA and 5-AZA-CdR separately and in combination. In D19 and D34, RAR $\beta$ expression was highest $(p<0.0001)$ when treated with a combination of $0.5 \mu \mathrm{M} 5$-AZA-CdR and $1 \mu \mathrm{M}$ ATRA. A concomitant increase in CDKN1A $(p<0.0001)$ and CDKN2A $(p<0.002)$ expression was noted when the cells were treated with ATRA and 5-AZA-CdR alone and/or in combinations (Figure 3A,B). D20 showed a re-expression of $\operatorname{RAR} \beta(p<0.0001)$ when treated with 5-AZA-CdR and ATRA combination, and CDKN1A re-expression was significant on treatment with $10 \mu \mathrm{M}$ ATRA $(p=0.0001)$, but changes in CDKN2A expression were not statistically significant (Figure 3A,B). In D38, RAR $\beta$ was re-expressed on ATRA treatment $(p<0.03)$. CDKN1A was expressed on treatment with ATRA in combination with 5-AZA-CdR $(p<0.0001)$, whereas there was no significant difference in CDKN2A expression (Figure 3A,B). Although the combination of 5-AZA-CdR and ATRA produced the highest levels of RAR $\beta$ in iPMOL cells, ATRA or 5-AZA-CdR alone when used in varying concentrations induced RAR $\beta$ re-expression $(p<0.05)$. These results imply that the response is cell-line-specific and dose-dependent.

In 3D TEM models, RAR $\beta$ staining of the models showed a significant increase in expression after treatment with ATRA (Figure 3C and Table 3). Under 5-AZA-CdR treatment (alone or in combination with ATRA), the 3D TEM models were insufficiently robust for further assessment (included for completeness in Figure 3C). 


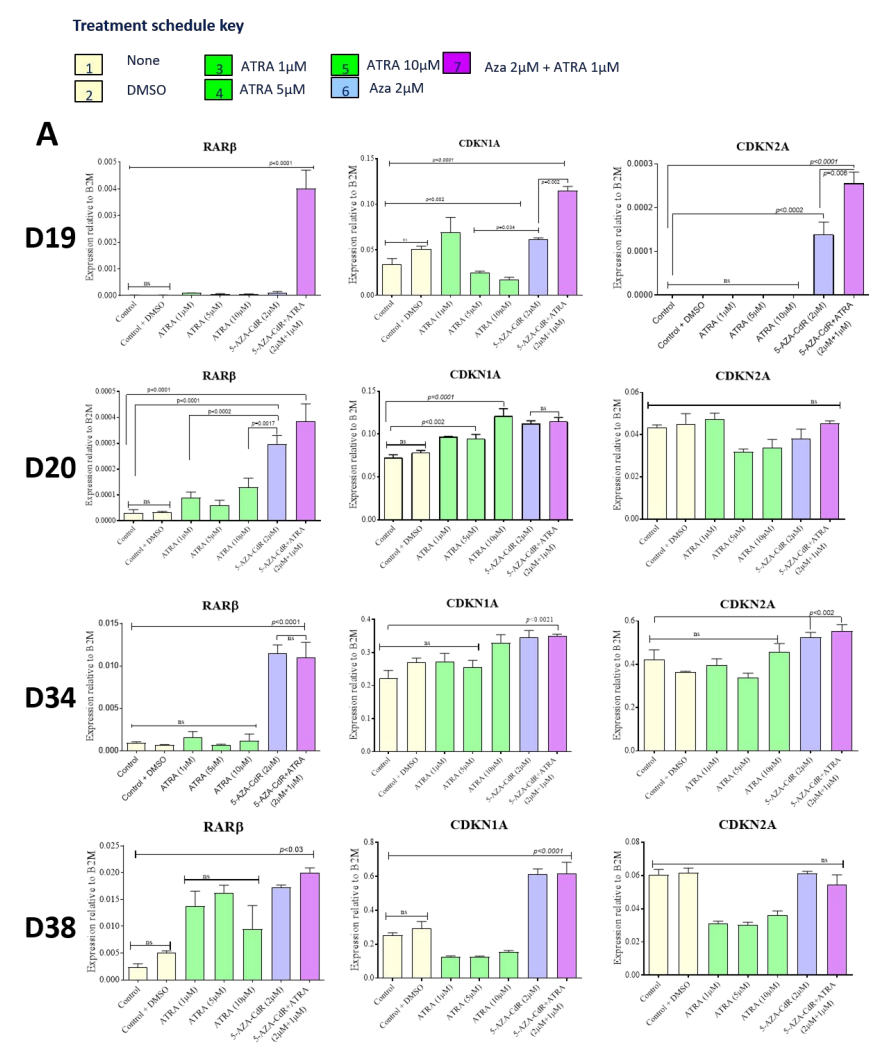

RAR $\beta$

B-actin

CDKN2A

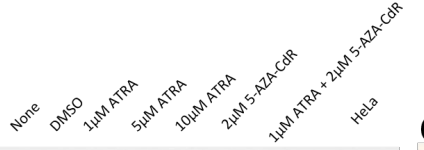

$-1----1-$
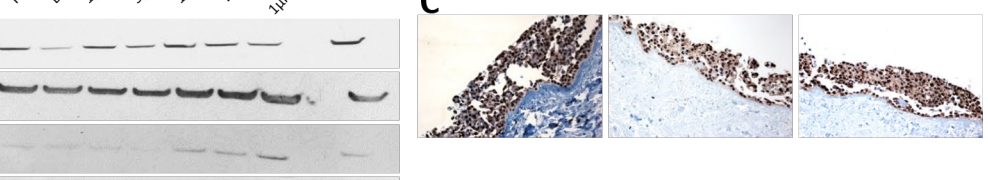

${ }_{\mathrm{RARB}}-\longrightarrow-(-\cdots-$

CDKN1A

CDKN2A
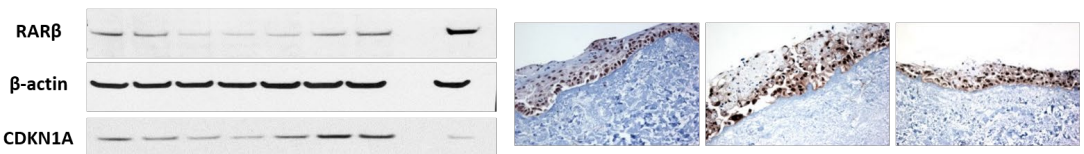

CDKN2A

RAR $\beta$

$\beta$-actin

CDKN1A

CDKN2A

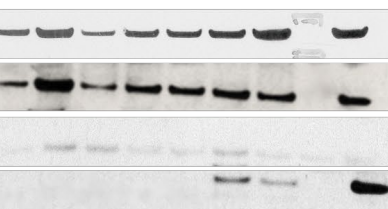

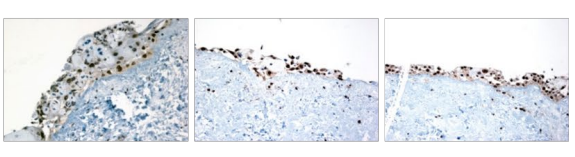

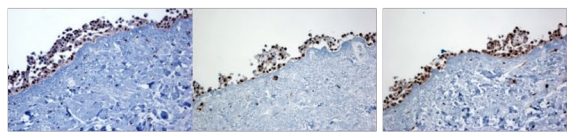

1 $\mu$ M ATRA $2 \mu \mathrm{M}$ 5-AZA-CdR Combination

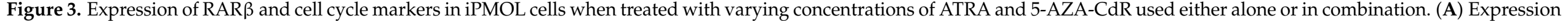

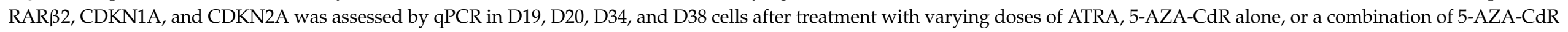

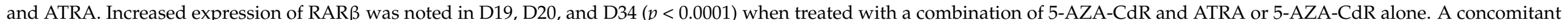

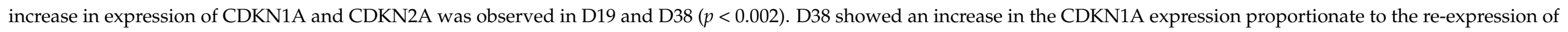

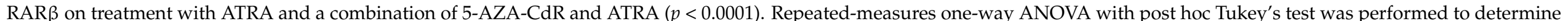

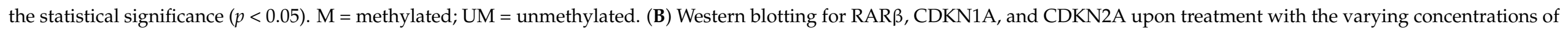

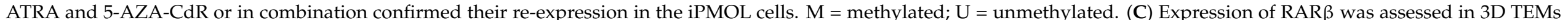

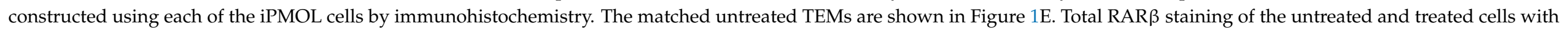

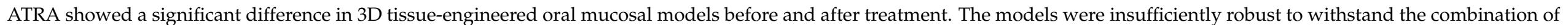
ATRA and 5-AZA-CdR. 
Table 3. RAR $\beta$ expression in 3D-tissue-engineered oral mucosa models before and after treatment with $1 \mu \mathrm{M}$ ATRA.

\begin{tabular}{ccc}
\hline 3D Models & RAR $\boldsymbol{\beta} \%$ before Treatment & RAR $\boldsymbol{\beta} \%$ after Treatment with $\mathbf{1} \boldsymbol{\mu M}$ ATRA \\
\hline D19 & 20.7 & 66.2 \\
D20 & 47.1 & 54.6 \\
D34 & 32.56 & 44.3 \\
D38 & 17.1 & 39.3 \\
\hline
\end{tabular}

We also identified changes in the expression of cRBP1 in these cultures (Figure 1A and Figure S1). Treatment with 5-Aza-CdR and 5-Aza-CdR + ATRA resulted in increased expression in D34 and D20, with little effect in D19 and D38 (Figure S1). The mechanism of this is unclear as the cRBP1 promoter did not show CpG island methylation in any case.

\subsection{Treatment with 5-Aza-CdR and ATRA Increases the Proportion of Senescent iPMOL Cells}

The HIRA foci assay showed an increased accumulation of senescence-associated heterochromatin foci (SAHF) in iPMOL cells when treated with the combination of 5-AZACdR with ATRA ( $p<0.0007$ : Figure 4A). D34 and D38 cells also showed a significant increase in HIRA foci when treated with varying concentrations of ATRA $(p<0.0001)$ or 5-AZA-CdR $(p<0.002)$ (Figure 4A).

The mean percentage values of senescence-associated $\beta$-galactosidase (Sa $\beta$-gal) activity increased upon treatment with ATRA and 5-AZA-CdR in D20, D34, and D38 $(p<0.0001)$ cells, and less so in D19, when compared to untreated cells (Figure 4B). However, D38 cells showed relatively uniform SA- $\beta$-gal positivity across the concentrations tested with or without combination, with only a small but significant increase $(p<0.0002)$. As with the HIRA foci assay, D34 and D38 cells showed a significant increase in SA- $\beta$-gal activity when treated with the various concentrations of ATRA or 5-AZA-CdR when compared to untreated cells $(p<0.0002$ : Figure 4B).

\subsection{ATRA and 5-AZA-CdR-Treated IMDs Show G2/M Arrest and Increased Sub-G0 Phase}

Treatment of the iPMOL cells with 5-AZA-CdR and 5-AZA-CdR + ATRA resulted in accumulation of cells in the G2 phase of the cell cycle in D19, D20, and D34, with little effect seen in D38 (Figure 5A-E) when compared to vehicle control (DMSO). The effect appeared to be primarily mediated by $5-\mathrm{AZA}-\mathrm{CdR}$, as ATRA alone had little effect nor further increased the G2 accumulation seen when used in combination with 5-AZA-CdR. Treatment with ATRA between 5-10 $\mu \mathrm{M}$ increased the proportion of cells in G1 for D19 only (Figure 5D), with a corresponding decrease of newly synthesised DNA. Apoptosis was assessed by quantifying sub-G0 content, which typically represents fragmented DNA. A small increase in sub-G0 events was seen with 5-AZA-CdR treatment of D19 cells (2.92\% vs. $0.73 \%$ vehicle control: Figure 5 C); this is unlikely to account for the significant reduction in S-phase DNA. 
A. HIRA

B. SA $\beta$-Gal
D19
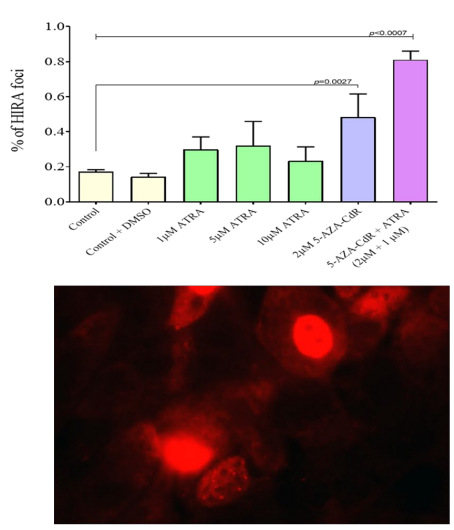

$1 \mu \mathrm{M}$ ATRA + 0.5 $\mu \mathrm{M}$ 5-AZA-CdR
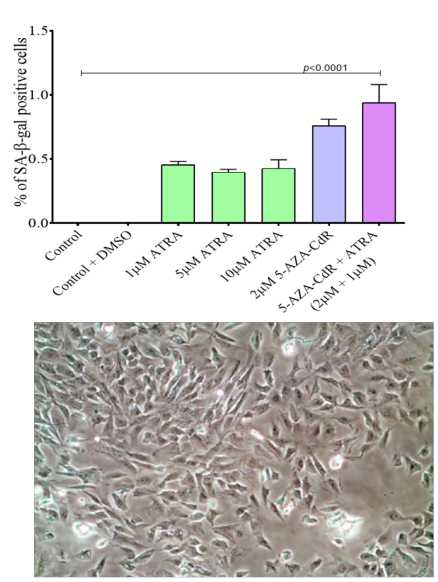

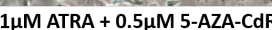

D20
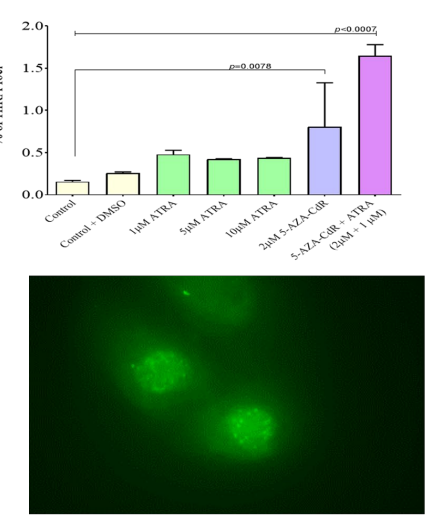

$1 \mu \mathrm{M}$ ATRA + 0.5 $\mu \mathrm{M}$ 5-AZA-CdR
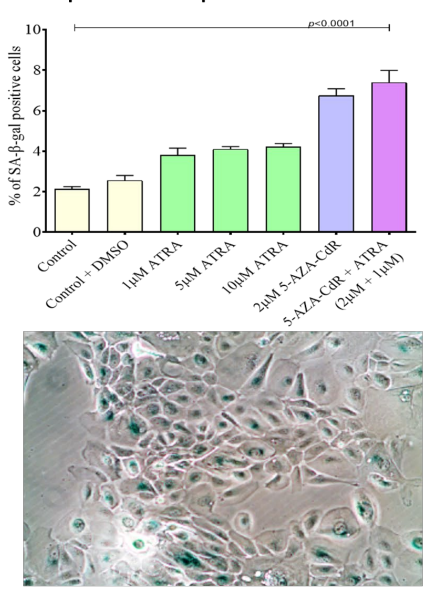

$1 \mu M$ ATRA + 0.5 $\mu M$ 5-AZA-CDR
D34
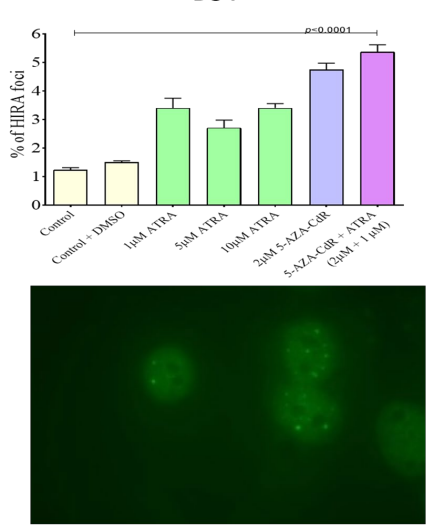

$1 \mu \mathrm{M}$ ATRA
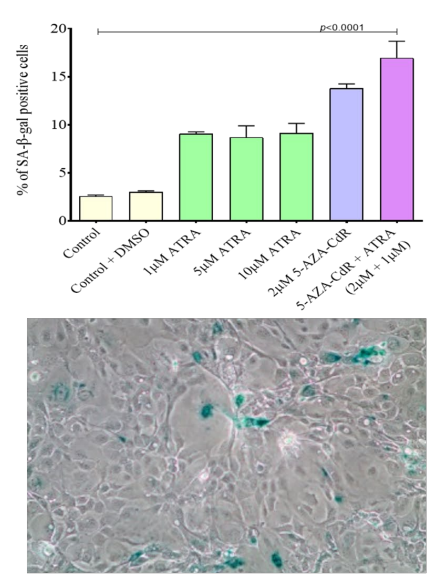

$1 \mu \mathrm{M}$ ATRA
D38
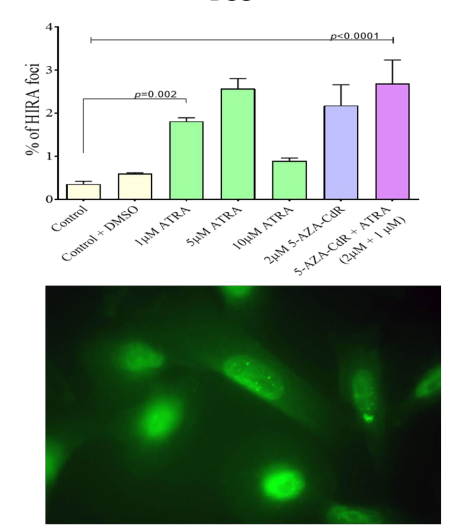

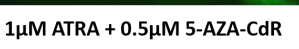
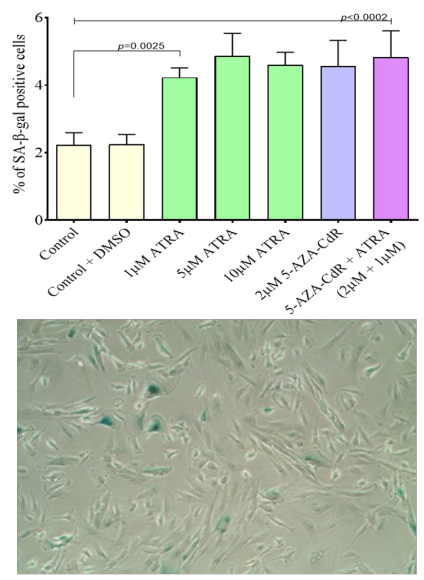

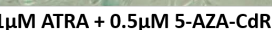

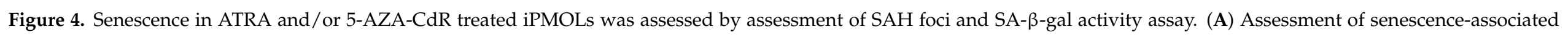

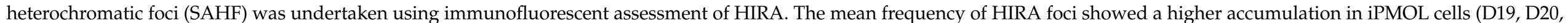

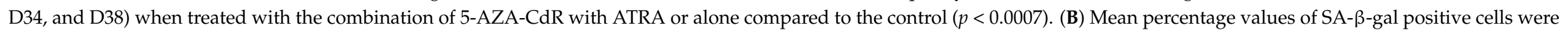

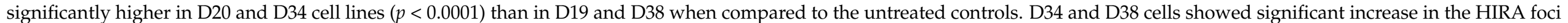

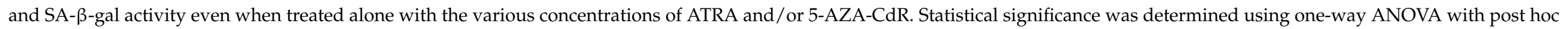
Dunnett's test $(p<0.05)$. 
A
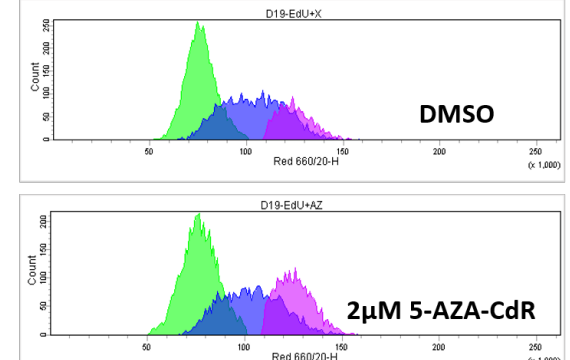

B
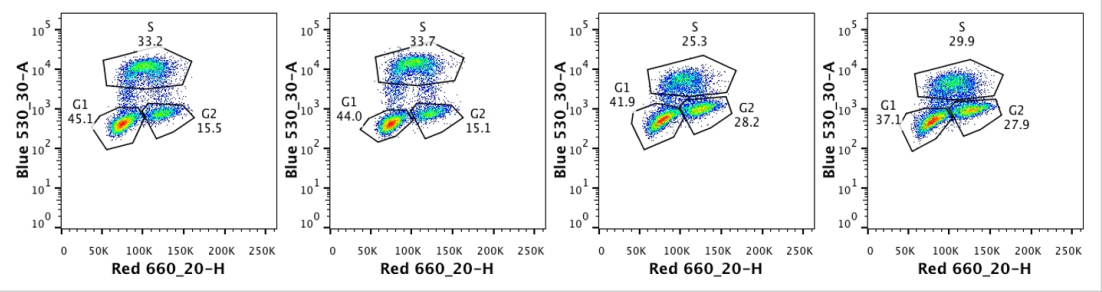

C

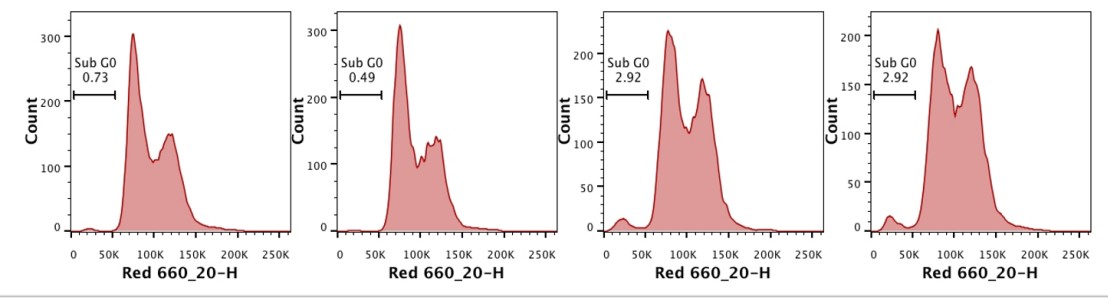

D1
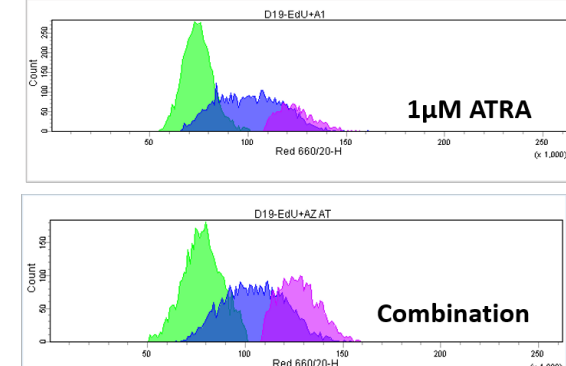

D34
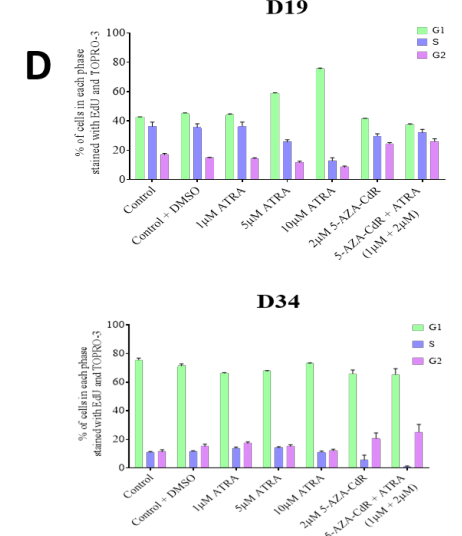

D19

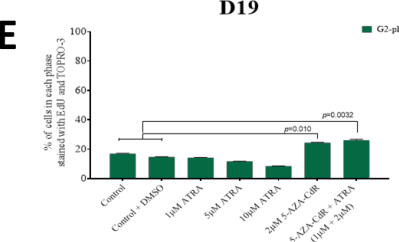

D34

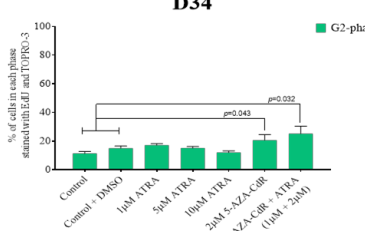

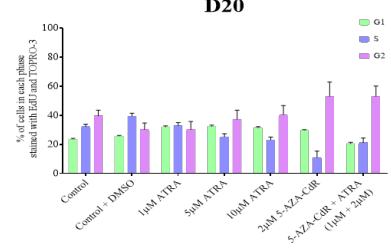

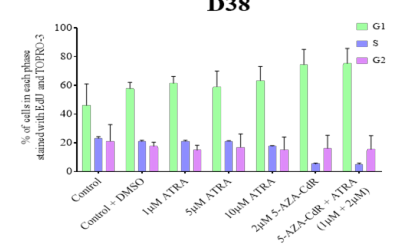

D20

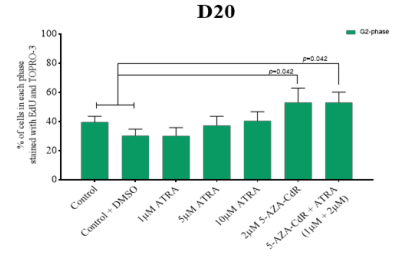

D38

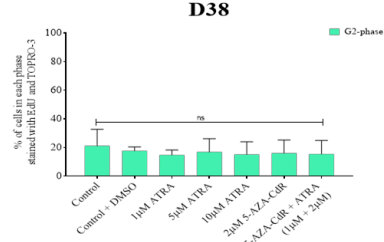

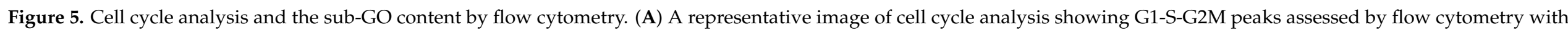

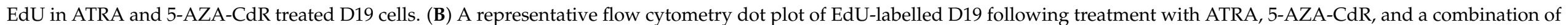

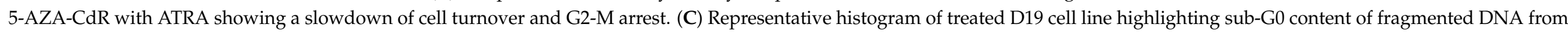

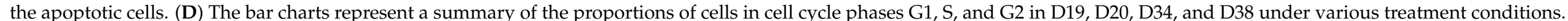

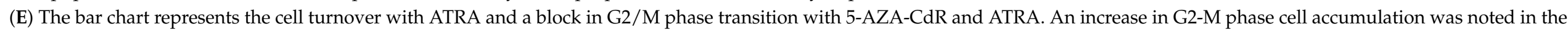
D19, D20, and D34 cell lines $(p<0.05)$, whereas no significant difference was noted in the D38 cell line by one-way ANOVA with post hoc Tukey's test. 


\section{Discussion}

The potential of the combination of effects of a methylating agent, such as 5-AZA-CdR with retinoids, has been explored in a number of different malignant and pre-neoplastic conditions [23-25]. The observation of loss of expression of some retinoid receptors by promoter methylation, associated with loss of retinoid sensitivity and thus retinoid-related modulation of differentiation and cell cycle arrest, indicates that this is potentially a useful concept for chemoprevention. However, cell culture data in many cases have been conducted on a very limited panel of cells, and, in some publications, only one. This leaves several open questions as to the variability of response which may be associated with the biological variability seen in the development of cancer and pre-neoplastic conditions. Proof of principle has already been established in PMOL and OSCC [16,17], but an in-depth assessment of the variability of response at the level of the effects on the cell cycle and replicative potential has not been reported.

Whilst the loss of RAR $\beta$ expression has been reported in OSCC tissues, this has not been explored in PMOL tissues. Previous work, confirmed and extended in this report, has demonstrated that RAR $\beta 2$ expression is lost in most immortal oral precancer cells (Figure 1A: [14]). This pattern of expression is reflected, to some extent, in the original tissues, but tissue expression of RAR $\beta$ varies. The tissues used for this assessment are those from the original diagnostic biopsy, from which half of the sample was used to derive the cell culture. The IHC staining pattern demonstrates that dysplastic oral mucosa consists of a mixed cell population of RAR $\beta$ expressing and RAR $\beta$ negative cells. Whilst it has not been possible to directly correlate this with other elements of the immortal phenotype in these tissues (p53 mutations, p16 loss, Telomerase activation), other studies have reported heterogeneity in PMOL oral mucosa, for example, the appearance of "patches" of p53 mutation, indictive of heterogeneous cell populations [37]. Given that some of the PMOL tissues gave rise to cell cultures that can senesce, it is likely that these lesions contain populations of cells with a mixed proliferative potential, and indeed, some cells may be senescent or at least retain the potential to senesce. The retention of these cells within PMOL mucosa may give the lesion a variable ability to respond to retinoids, as seen in the numerous clinical studies reported over many years [6,8-10]. The expression of RAR $\beta$ in the TEM models is higher than in the original parent tissues (Figure 1E), which is expected when using a single cell population for the generation of these models: however, there is variability in expression, and an increase in expression is seen on ATRA treatment (Table 3). This may indicate complex effects of differentiation in the 3D model which are not seen in monolayer culture and which will require further investigation.

Previous studies of retinoid receptor expression in PMOL tissues are very limited and hampered by a lack of sufficiently specific antibodies: indeed, the antibodies used in this study have been challenging to use. They are not specific for RAR $\beta 2$ and will pick up other RAR $\beta$ isoforms, which may explain the discrepancies between the qPCR and WB data. The overall expression of RARs and RXRs appears to be increased in PMOL and SCC, indicating complex changes in the spectrum of retinoid receptors in OSCC development [38,39], but protein expression of subtypes beyond this has not been reported. Studies using in situ hybridisation for RAR and RXR mRNA demonstrate loss of RAR $\beta$ expression in about $50 \%$ of lesions with a further reduction in OSCC, keeping with our findings [40].

RAR $\beta 2$ is re-expressed following administration of $5^{\prime} \mathrm{AzaC}$ to a variable extent: markedly in 2/4 cell lines tested (D19 and D34), to a much lesser degree in one (D20), and not at all in another (D38: Figure 2A). D38 is unusual in as much as it is immortal but has retained wild type p53 [16]. It also has retained the ability to increase RAR $\beta$ expression on treatment with ATRA (Figure 3). In most of these iPMOL cell cultures, the lack of RAR $\beta$ expression is accompanied by methylation of $\mathrm{CpG}$ islands in the RAR $\beta$ promoter (Figure 2). The modulation of RAR $\beta$ expression by this mean appears to be an initial, reversible effect in oral cancer development, as tissues from later in the process show loss of expression by non-reversible means, such as chromosome $3 p$ deletion [41]. Mortal oral precancer cells retain RAR $\beta 2$ expression (D6 and D30: Figure 1A), and this is constitutive, rather 
than only upon RA exposure, which would normally be the case in normal oral epithelial cells [14]. In D20, the dynamic range of the increase in RAR $\beta 2$ expression is much less than in D19 and D34. Furthermore, treatment with 5-AZA-CdR does not result in an increase in unmethylated CPG islands on the RAR $\beta$ promoter; thus, the effects seen may be unrelated to any effect on this promoter.

Expression of the retinoid-binding protein cRBP1 is also increased in D20 and D34 on treatment with 5-AZA-CdR, with no additional effect of ATRA treatment (Figure S1). No change in expression was noted in D38. Parallel changes in cRBP1 expression may be required for retinoid function.

In cells that re-express RAR $\beta 2$, treatment with ATRA and 5-AZA-CdR in combination results in accumulation of cells in G2 (Figure 5) and increases in the senescence markers SAB-Gal and HIRA (Figure 4). The cell cycle effects seen are maximal on treatment with 5-Aza-CdR alone, and the addition of ATRA results in little additional change. This maintains the known effects of 5-AZA-CdR treatment on the cell cycle, which initiates a G2 arrest [42]. As retinoids induce cell cycle arrest in G1 [43], it appears that the effects of these treatment schedules on the cell cycle are dominated by the overall effect of 5-AZA-CdR. This somewhat calls into question the additional benefit of ATRA treatment. However, in relation to senescence, the addition of ATRA confers an additional increase in the proportion of cells exhibiting senescence markers in D19 and less so in D20. Additionally, treatment with 5-AZA-CdR increases the proportion of cells with markers of senescence in D34, as has been previously reported [16]. This is not further increased by the addition to ATRA. There is very little effect on the cell cycle or on senescence markers in D38.

The effects seen on the expression of p16 ink4a and p21 support the cell cycle effects seen. In D19 and D34, in which the most marked effects on the cell cycle are seen, treatment with 5-AZA-CdR results in expression of $\mathrm{p} 16^{\mathrm{ink} 4 \mathrm{a}}$ and $\mathrm{p} 21$, whilst no effects were seen in D20. Conversely, D38, which has wild-type p53, shows strong induction of p21 on 5-AZACdR and combined 5-AZA-CdR +ATRA treatment (Figure 5A), but no consistent effects on ether the cell cycle or induction of senescence. Loss of p16 ${ }^{\text {ink4a }}$ expression, initially by promoter methylation, has been demonstrated as an early event in OSCC development and has been described in PMOLs [44,45]. Thus, some of the effects seen in the cell cycle and senescence may be due to the re-expression of $\mathrm{p} 16^{\text {ink4a }}$ mediated by 5-AZA-CdR. However, p16 mediated pro-senescence effects have long been associated with arrest in G1, which has not been demonstrated in this study. More recent investigations have shown that the senescence program can be initiated in G2 and that p21 is an important mediator of this process [46]. Whilst it is possible that some of the effects on the expression of p21 indicate that senescence is also being induced via p21 at this point in the cell cycle (in addition to the direct 5-AZA-CdR-mediated accumulation of cells in G2), the lack of effects seen in D38, which has retained WTp53, does not support this conclusion.

Overall, the results presented demonstrate the variability in response to these agents in cell culture. Response to treatment (defined as an increase in senescence markers and/or alteration in the cell cycle) is variably related to the ability to re-express RAR $\beta 2, c R B P 1$, and $\mathrm{p} 16^{\mathrm{ink} 4 \mathrm{a}}$ in iPMOL cells, but the majority of the effect is seen upon treatment with 5-Aza-CdR alone, with only modest additional effects on treatment with ATRA, even in circumstances where RAR $\beta$ is re-expressed. Assessment of all these factors would be needed in patient samples to predict the response to therapy with retinoid and demethylation agents. Furthermore, it is true that assessment of these effects in monolayer cell culture is sub-optimal for assessment of effects (particularly in the assessment of effects on differentiation and the potential effects of the stroma on retinoid metabolism) and use of a more robust 3D TEM model may be required [47]. Our initial investigations of this have found that 3D mucosal models produced using our standard procedures are insufficiently robust to withstand 5-Aza-CdR treatment (Figure 3C).

However, the effects on the D34 effect suggests that a beneficial effect may be possible, as has been previously suggested [16]. As most of the effects seen in this cell culture system are mediated by $5-A z a-C d R$, it is unclear how much extra benefit is gained by the addition 
of ATRA. Additionally, increased efficacy has been demonstrated in other 2D and 3D cell culture systems by the use of newer synthetic retinoids [48], and investigation of the effects of these may also demonstrate increased effects in oral cells.

\section{Conclusions}

In conclusion, RAR $\beta$ is constitutively expressed in the mortal dysplastic cells, which undergo replicative senescence. Loss of RAR $\beta$ by promoter methylation, along with the inactivation of p16 and activation of telomerase, is associated with immortalisation in dysplastic keratinocytes. Treatment of immortal dysplastic cells with 5-AZA-CdR in combination with ATRA leads to the re-expression of RAR $\beta$ (and in some cases, p16), with a resultant increase in senescence. The explanation for the repression of RAR $\beta$ expression in D19, D20, and D34 was promoter hypermethylation, emphasising epigenetic mechanisms in oral cancer pathogenesis, and the importance of the combination of drugs for chemoprevention. However, defining the extent to which ATRA per se contributes to these effects is difficult, given the wider effects of 5-AZA-CdR in these cells.

Supplementary Materials: The following are available online at https:/ /www.mdpi.com/article/10 .3390/cancers13164064/s1, Figure S1: Expression of cRBP1 under AZA-C and ATRA treatment as assessed by qPCR. The pattern of expression in D19 is very similar to that in D34.

Author Contributions: Conceptualisation, R.R. and K.D.H.; Data curation, R.R.; Formal analysis, R.R., H.L.C., M.D., K.S.R.P. and K.D.H.; Funding acquisition, K.D.H.; Investigation, R.R., H.L.C. and M.D.; Methodology, R.R., H.L.C., M.D. and K.S.R.P.; Project administration, K.D.H.; Supervision, K.D.H.; Writing—original draft, K.D.H.; Writing—review and editing, R.R., H.L.C., M.D., K.S.R.P. and K.D.H. All authors have read and agreed to the published version of the manuscript.

Funding: This research was funded by the European Commission FP7 Marie Curie Incoming Fellowship, grant number PIIF-GA-2012-327300.

Institutional Review Board Statement: The study was conducted according to the guidelines of the Declaration of Helsinki and approved by the National Research Ethics Service (ref: 08/S0709/70, Sheffield Teaching Hospitals Project Reference: 15753).

Informed Consent Statement: The ethical approval and NHS regulatory authorisation allow for the use of surplus diagnostic tissue in a linked anonymised format without the requirement for specific consent from each patient.

Data Availability Statement: The data presented in this study are available on request from the corresponding author.

Conflicts of Interest: The authors declare no conflict of interest.

\section{References}

1. Brouns, E.; Baart, J.; Karagozoglu, K.; Aartman, I.; Bloemena, E.; Van Der Waal, I. Malignant transformation of oral leukoplakia in a well-defined cohort of 144 patients. Oral Dis. 2013, 20, e19-e24. [CrossRef]

2. Warnakulasuriya, K.; Kovacevic, T.; Madden, P.; Coupland, V.H.; Sperandio, M.; Odell, E.; Moller, H. Factors predicting malignant transformation in oral potentially malignant disorders among patients accrued over a 10-year period in South East England. J. Oral Pathol. Med. 2011, 40, 677-683. [CrossRef]

3. Celentano, A.; Glurich, I.; Borgnakke, W.S.; Farah, C.S. World Workshop on Oral Medicine VII: Prognostic biomarkers in oral leukoplakia and proliferative verrucous leukoplakia-A systematic review of retrospective studies. Oral Dis. 2021, 27, 848-880. [CrossRef]

4. Tabor, M.P.; Brakenhoff, R.H.; Van Houten, V.M.; Kummer, J.A.; Snel, M.H.; Snijders, P.J.; Snow, G.B.; Leemans, C.R.; Braakhuis, B.J. Persistence of genetically altered fields in head and neck cancer patients: Biological and clinical implications. Clin. Cancer Res. 2001, 7, 1523-1532. [PubMed]

5. Fryer, J.H. VII The Role of Nutrition in Oral Leukoplakia. Ann. Otol. Rhinol. Laryngol. 1961, 70, 102-117. [CrossRef]

6. Hong, W.K.; Endicott, J.; Itri, L.M.; Doos, W.; Batsakis, J.G.; Bell, R.; Fofonoff, S.; Byers, R.; Atkinson, E.N.; Vaughan, C.; et al. 13-cis-Retinoic Acid in the Treatment of Oral Leukoplakia. N. Engl. J. Med. 1986, 315, 1501-1505. [CrossRef] [PubMed]

7. Lippman, S.M.; Garewal, H.S.; Meyskens, F.L. Retinoids as potential chemopreventive agents in squamous cell carcinoma of the head and neck. Prev. Med. 1989, 18, 740-748. [CrossRef] 
8. Papadimitrakopoulou, V.A.; Lee, J.J.; William, W.N., Jr.; Martin, J.W.; Thomas, M.; Kim, E.S.; Khuri, F.R.; Shin, D.M.; Feng, L.; Hong, W.K.; et al. Randomized Trial of 13-cis Retinoic Acid Compared with Retinyl Palmitate with or without Beta-Carotene in Oral Premalignancy. J. Clin. Oncol. 2009, 27, 599-604. [CrossRef]

9. William, W.N.; Lee, J.J.; Lippman, S.M.; Martin, J.W.; Chakravarti, N.; Tran, H.T.; Sabichi, A.L.; Kim, E.S.; Feng, L.; Lotan, R.; et al. High-Dose Fenretinide in Oral Leukoplakia. Cancer Prev. Res. 2009, 2, 22-26. [CrossRef] [PubMed]

10. Toma, S.; Bonelli, L.; Sartoris, A.; Mira, E.; Antonelli, A.; Beatrice, F.; Giordano, C.; Benazzo, M.; Caroggio, A.; Cavalot, A.L.; et al. 13-cis retinoic acid in head and neck cancer chemoprevention: Results of a randomized trial from the Italian Head and Neck Chemoprevention Study Group. Oncol. Rep. 2004, 11, 1297-1305. [CrossRef]

11. Lele, S. Although leukoplakia responds to some treatments relapses and adverse effects are common. Evid. Based Dent. 2005, 6, 15-16. [CrossRef]

12. Lodi, G.; Franchini, R.; Warnakulasuriya, S.; Varoni, E.M.; Sardella, A.; Kerr, A.R.; Carrassi, A.; MacDonald, L.C.; Worthington, H. Interventions for treating oral leukoplakia to prevent oral cancer. Cochrane Database Syst. Rev. 2016, 7, CD001829. [CrossRef]

13. Lotan, R. Suppression of squamous cell carcinoma growth and differentiation by retinoids. Cancer Res. 1994, 54, 1987s-1990s. [PubMed]

14. McGregor, F.; Wagner, E.; Felix, D.; Soutar, D.; Parkinson, K.; Harrison, P.R. Inappropriate retinoic acid receptor-beta ex-pression in oral dysplasias: Correlation with acquisition of the immortal phenotype. Cancer Res. 1997, 57, 3886-3889. [PubMed]

15. Lotan, R. Roles of retinoids and their nuclear receptors in the development and prevention of upper aerodigestive tract cancers. Environ. Health Perspect. 1997, 105, 985-988. [CrossRef] [PubMed]

16. McGregor, F.; Muntoni, A.; Fleming, J.; Brown, J.; Felix, D.H.; Macdonald, D.G.; Parkinson, E.K.; Harrison, P.R. Molecular changes associated with oral dysplasia progression and acquisition of immortality: Potential for its reversal by 5-azacytidine. Cancer Res. 2002, 62, 4757.

17. Youssef, E.M.; Lotan, D.; Issa, J.-P.; Wakasa, K.; Fan, Y.-H.; Mao, L.; Hassan, K.; Feng, L.; Lee, J.J.; Lippman, S.M.; et al. Hypermethylation of the Retinoic Acid Receptor- $\beta 2$ Gene in Head and Neck Carcinogenesis. Clin. Cancer Res. 2004, 10, 1733-1742. [CrossRef]

18. Napoli, J.L. Functions of Intracellular Retinoid Binding-Proteins. Prokaryotic Cytoskelet. 2016, 81, 21-76. [CrossRef]

19. Fabricius, E.-M.; Kruse-Boitschenko, U.; Schneeweiss, U.; Wildner, G.-P.; Hoffmeister, B.; Raguse, J.-D. Model examinatiö̈ $i \frac{1}{2} \mathrm{n}$ of chemoprevention with retinoids in squamous cell carcinomas of the head and neck region and suitable biomarkers for chemoprevention. Int. J. Oncol. 2011, 39, 1083-1097. [CrossRef]

20. Copper, M.; Klaassen, I.; Brakenhoff, R.; Cloos, J.; Snow, G.; Braakhuis, B. All-trans retinoic acid induced gene expression and growth inhibition in head and neck cancer cell lines. Oral Oncol. 1997, 33, 270-274. [CrossRef]

21. Raif, A.; Marshall, G.M.; Bell, J.L.; Koach, J.; Tan, O.; D’Andreti, C.; Thomas, W.; Sekyere, E.; Norris, M.; Haber, M.; et al. The estrogen-responsive B box protein (EBBP) restores retinoid sensitivity in retinoid-resistant cancer cells via effects on histone acetylation. Cancer Lett. 2009, 277, 82-90. [CrossRef] [PubMed]

22. Smith, B. Prognostic factors in patients with head and neck cancer. In Head and Neck Cancer: A Multidisciplinary Approach; Harrison, L.B., Hong, W.K., Sessions, R.B., Eds.; Lippincott Williams and Wilkins: Philadelphia, PA, USA, 2008; ISBN $978-0781771368$.

23. Xiang, L.; Wang, R.; Weiying, G.; Qiu, G.; Cen, J.; Hu, S.; Xie, X.; Chen, Z.; Guoqiang, Q. Retinoic Acid Receptor- $\beta$ Gene Reexpression and Biological Activity in SHI-1 Cells after Combined Treatment with 5-Aza-2'-Deoxycytidine and All-Trans Retinoic Acid. Acta Haematol. 2015, 133, 279-286. [CrossRef] [PubMed]

24. Cao, Y.; Liu, Y.; Shang, L.; Wei, W.; Shen, Y.; Gu, Q.; Xie, X.; Dong, W.; Lin, Y.; Yue, Y.; et al. Decitabine and all-trans retinoic acid synergistically exhibit cytotoxicity against elderly AML patients via miR-34a/MYCN axis. Biomed. Pharmacother. 2020, 125, 109878. [CrossRef] [PubMed]

25. Westerlund, I.; Shi, Y.; Toskas, K.; Fell, S.M.; Li, S.; Surova, O.; Södersten, E.; Kogner, P.; Nyman, U.; Schlisio, S.; et al. Combined epigenetic and differentiation-based treatment inhibits neuroblastoma tumor growth and links HIF2 $\alpha$ to tumor suppression. Proc. Natl. Acad. Sci. USA 2017, 114, e6137-e6146. [CrossRef] [PubMed]

26. Yang, Q.; Shan, L.; Yoshimura, G.; Nakamura, M.; Nakamura, Y.; Suzuma, T.; Umemura, T.; Mori, I.; Sakurai, T.; Kakudo, K. 5 -aza-2'-deoxycytidine induces retinoic acid receptor beta 2 demethylation, cell cycle arrest and growth inhibition in breast carcinoma cells. Anticancer Res. 2003, 22, 2753-2756.

27. Muntoni, A.; Fleming, J.; Gordon, K.E.; Hunter, K.; McGregor, F.; Parkinson, E.K.; Harrison, P.R. Senescing oral dysplasias are not immortalized by ectopic expression of hTERT alone without other molecular changes, such as loss of INK4A and/or retinoic acid receptor- $\beta$ : But p53 mutations are not necessarily required. Oncogene 2003, 22, 7804-7808. [CrossRef]

28. Livak, K.J.; Schmittgen, T.D. Analysis of relative gene expression data using real-time quantitative PCR and the 2(-Delta Delta C(T)) Method. Methods 2001, 25, 402-408. [CrossRef]

29. Buck, S.B.; Bradford, J.; Gee, K.R.; Agnew, B.J.; Clarke, S.T.; Salic, A. Detection of S-phase cell cycle progression using 5-ethynyl-2' deoxyuridine incorporation with click chemistry, an alternative to using 5-bromo-2'-deoxyuridine antibodies. Biotechniques 2008, 44, 927-929. [CrossRef]

30. Holemon, H.; Korshunova, Y.; Ordway, J.; Bedell, J.; Citek, R.; Lakey, N.; Leon, J.; Finney, M.; McPherson, J.; Jeddeloh, J. MethylScreen: DNA methylation density monitoring using quantitative PCR. Biotechniques 2007, 43, 683-693. [CrossRef]

31. Herman, J.G.; Graff, J.R.; Myohanen, S.; Nelkin, B.D.; Baylin, S.B. Methylation-specific PCR: A novel PCR assay for methylation status of CpG islands. Proc. Natl. Acad. Sci. USA 1996, 93, 9821-9826. [CrossRef] 
32. Côté, S.; Sinnett, D.; Momparler, R.L. Demethylation by 5-aza-2'-deoxycytidine of specific 5-methylcytosine sites in the promoter region of the retinoic acid receptor beta gene in human colon carcinoma cells. Anti-Cancer Drugs 1998, 9, 743-750. [CrossRef]

33. Xiong, Z.; Laird, P.W. COBRA: A sensitive and quantitative DNA methylation assay. Nucleic Acids Res. 1997, 25, 2532-2534. [CrossRef]

34. Dimri, G.P.; Lee, X.; Basile, G.; Acosta, M.; Scott, G.; Roskelley, C.; Medrano, E.E.; Linskens, M.; Rubelj, I.; Pereira-Smith, O.; et al. A biomarker that identifies senescent human cells in culture and in aging skin in vivo. Proc. Natl. Acad. Sci. USA 1995, 92, 9363-9367. [CrossRef] [PubMed]

35. Colley, H.E.; Hearnden, V.; Jones, A.V.; Weinreb, P.; Violette, S.M.; MacNeil, S.; Thornhill, M.; Murdoch, C. Development of tissue-engineered models of oral dysplasia and early invasive oral squamous cell carcinoma. Br. J. Cancer 2011, 105, 1582-1592. [CrossRef]

36. Niklander, S.E.; Crane, H.L.; Darda, L.; Lambert, D.W.; Hunter, K.D. The role of icIL-1RA in keratinocyte senescence and development of the senescence-associated secretory phenotype. J. Cell Sci. 2021, 134, 134. [CrossRef]

37. Van Houten, V.M.; Tabor, M.P.; Brekel, M.W.V.D.; Kummer, J.A.; Denkers, F.; Dijkstra, J.; Snow, G.B.; Brakenhoff, R.H. Mutated p53 as a molecular marker for the diagnosis of head and neck cancer. J. Pathol. 2002, 198, 476-486. [CrossRef] [PubMed]

38. Sherman, J.; Partridge, M. Expression of retinoic acid receptors in normal, dysplastic and malignant oral epithelia. Br. J. Oral Maxillofac. Surg. 1997, 35, 260-266. [CrossRef]

39. Chakravarti, N.; Mathur, M.; Bahadur, S.; Shukla, N.K.; Rochette-Egly, C.; Ralhan, R. Expression of RARalpha and RARbeta in human oral potentially malignant and neoplastic lesions. Int. J. Cancer 2001, 91, 27-31. [CrossRef]

40. Xu, X.C.; Ro, J.Y.; Lee, J.S.; Shin, D.M.; Hong, W.K.; Lotan, R. Differential expression of nuclear retinoid receptors in normal, premalignant, and malignant head and neck tissues. Cancer Res. 1994, 54, 3580-3587. [PubMed]

41. Geradts, J.; Chen, J.Y.; Russell, E.K.; Yankaskas, J.R.; Nieves, L.; Minna, J.D. Human lung cancer cell lines exhibit resistance to retinoic acid treatment. Cell Growth Differ. Mol. Biol. J. Am. Assoc. Cancer Res. 1993, 4, 799-809.

42. Alexander, V.M.; Roy, M.; Steffens, K.A.; Kunnimalaiyaan, M.; Chen, H. Azacytidine induces cell cycle arrest and suppression of neuroendocrine markers in carcinoids. Int. J. Clin. Exp. Med. 2010, 3, 95-102.

43. Wilcken, N.R.; Musgrove, E.A.; Sutherland, R.L. Different points of action of retinoids and anti-estrogens in G1 phase identified in synchronized T-47D breast cancer cells. Int. J. Cancer 1997, 70, 291-296. [CrossRef]

44. Loughran, O.; Malliri, A.; Owens, D.; Gallimore, P.; Stanley, M.; Ozanne, B.; Frame, M.; Parkinson, E. Association of $\mathrm{CDKN2A} / \mathrm{p} 16 \mathrm{INK} 4 \mathrm{~A}$ with human head and neck keratinocyte replicative senescence: Relationship of dysfunction to immortality and neoplasia. Oncogene 1996, 13, 561-568.

45. Hall, G.L.; Shaw, R.J.; Field, E.A.; Rogers, S.N.; Sutton, D.N.; Woolgar, J.A.; Lowe, D.; Liloglou, T.; Field, J.; Risk, J.M. p16 Promoter Methylation Is a Potential Predictor of Malignant Transformation in Oral Epithelial Dysplasia. Cancer Epidemiol. Biomark. Prev. 2008, 17, 2174-2179. [CrossRef]

46. Gire, V.; Dulić, V. Senescence from G2 arrest, revisited. Cell Cycle 2015, 14, 297-304. [CrossRef] [PubMed]

47. Devalaraja, S.; To, T.K.J.; Folkert, I.W.; Natesan, R.; Alam, Z.; Li, M.; Tada, Y.; Budagyan, K.; Dang, M.T.; Zhai, L.; et al. Tumor-Derived Retinoic Acid Regulates Intratumoral Monocyte Differentiation to Promote Immune Suppression. Cell 2020, 180, 1098-1114.e16. [CrossRef] [PubMed]

48. Aouad, P.; Saikali, M.; Abdel-Samad, R.; Fostok, S.; El-Houjeiri, L.; Pisano, C.; Talhouk, R.; Darwiche, N. Antitumor activities of the synthetic retinoid ST1926 in two-dimensional and three-dimensional human breast cancer models. Anti-Cancer Drugs 2017, 28, 757-770. [CrossRef] [PubMed] 